\title{
Hydrogeochemical Characteristics and Assessment of Drinking Water Quality in the Urban Area of Zamora, Mexico
}

\author{
Claudia Alejandra Reyes-Toscano ${ }^{1}$, Ruth Alfaro-Cuevas-Villanueva ${ }^{2, *}$, Raúl Cortés-Martínez ${ }^{3}{ }^{\circledR}$, \\ Ofelia Morton-Bermea ${ }^{4}{ }^{\mathbb{D}}$, Elizabeth Hernández-Álvarez ${ }^{4}$, Otoniel Buenrostro-Delgado ${ }^{2}$ and \\ Jorge Alejandro Ávila-Olivera ${ }^{2}$ (1) \\ 1 Maestría en Ciencias en Ingeniería Ambiental, Universidad Michoacana de San Nicolás de Hidalgo, \\ Edif. M, C.U., Morelia 58030, Mexico; claudia_ale93@hotmail.com \\ 2 Instituto de Investigaciones en Ciencias de la Tierra, Universidad Michoacana de San Nicolás de Hidalgo, \\ Edificio U3, C.U., Morelia 58030, Mexico; otonielb@umich.mx (O.B.-D.); jaavila@umich.mx (J.A.Á.-O.) \\ 3 Facultad de Químico Farmacobiología, Universidad Michoacana de San Nicolás de Hidalgo, \\ Tzintzuntan 173, Colonia Matamoros, Morelia 58240, Mexico; rcortesm@umich.mx \\ 4 Instituto de Geofísica, Universidad Nacional Autónoma de México. Circuito Exterior S/N, \\ Ciudad Universitaria, Mexico D.F. 04510, Mexico; omorton@geofisica.unam.mx (O.M.-B.); \\ ehalvarez@yahoo.com.mx (E.H.-Á.) \\ * Correspondence: racv11@gmail.com; Tel.: +52-443-340-5079
}

Received: 31 December 2019; Accepted: 4 February 2020; Published: 17 February 2020 updates

\begin{abstract}
This work assessed the groundwater hydrogeochemistry and the drinking water quality of 10 wells supplying the urban area of Zamora, Michoacán, Mexico. Two sampling campaigns were conducted in May 2018 (dry season) and November 2018 (wet season) to describe the chemistry of the water and its interaction with the rock. Physical and chemical constituents (temperature, $\mathrm{pH}$, electrical conductivity, color, turbidity, solids, total hardness, total alkalinity, chemical and biochemical oxygen demands), major components $\left(\mathrm{Ca}^{2+}, \mathrm{Mg}^{2+}, \mathrm{Na}^{+}, \mathrm{K}^{+}, \mathrm{SO}_{4}{ }^{2-}, \mathrm{PO}_{4}{ }^{3-}, \mathrm{HCO}_{3}{ }^{-}, \mathrm{CO}_{3}{ }^{2-}, \mathrm{Cl}^{-}, \mathrm{N}^{-} \mathrm{NO}_{3}{ }^{-}\right.$, and $\mathrm{N}_{-} \mathrm{NH}_{3}$ ), as well as trace elements (As, $\mathrm{Fe}, \mathrm{Mn}, \mathrm{Ba}, \mathrm{Al}, \mathrm{Sb}, \mathrm{Co}, \mathrm{V}, \mathrm{Cu}, \mathrm{Cd}, \mathrm{Cr}, \mathrm{Ni}, \mathrm{Zn}, \mathrm{Tl}, \mathrm{Pb}$ ) were analyzed. Results showed groundwater with a slight tendency to alkalinity. The hydrogeochemical facies observed are $\mathrm{Ca}^{2+}-\mathrm{HCO}_{3}{ }^{-}$in all sites. Hydrochemical diagrams indicate immature, cold, non-saline, and uncontaminated water with short residence time. Water-rock interaction predominates. The water in the study area is appropriate for drinking use according to Mexican and international regulations with an excellent quality in 7 wells and good in the other 3 .
\end{abstract}

Keywords: groundwater; water chemistry; hydrogeochemistry; hydrogeochemical facies; drinking water; Zamora; Mexico; water quality index

\section{Introduction}

Groundwater is one of the most valuable natural resources, playing a fundamental role in human health and wellness, socio-economic development, and ecosystem functioning. Moreover, it is widely used for various domestic, industrial, and irrigation activities [1].

In recent decades, groundwater pollution has become one of the most severe problems in the world, as water can be affected from natural sources or from numerous types of human activities, which can result in poor drinking water quality, water supply losses, high cleaning costs and potential health problems [2]. 
Groundwater quality is based on the behavior of physical and chemical parameters that are influenced by geological formations, atmospheric precipitation, inland surface water, and geochemical processes as they are in contact with the rock and the various anthropogenic activities [3].

Water chemistry provides valuable information to determine the origin, transit time, flow patterns and water regimes, geological structure, and mineralogy of aquifers, as well as hydrogeochemical processes. Specific water quality is required to meet both domestic and irrigation needs. Their monitoring and evaluation are essential to design preventive measures on human health, animal life, and vegetation [4].

Geographic Information Systems (GIS) play an important role in understanding and managing water resources and in the study of their pollution, which together with hydrogeochemical analysis, can be important tools in the exploitation of this natural resource [5].

Zamora, Michoacán has an aquifer consisting of basaltic, pyroclastic, alluvial materials, and lake deposits [6]. This city uses this resource to supply drinking water, obtaining it by pumping into wells.

The objective of this research was to carry out a geochemical study of the groundwater used as drinking water in Zamora, Mexico, by analyzing physicochemical parameters, major ions, and trace elements, together with chemical speciation, hydrogeochemical relationships, and spatial distribution maps.

\section{Materials and Methods}

\subsection{Location of the Study Area}

The city of Zamora belongs to the Bajío Region in the State of Michoacán, Mexico. It is located between the parallels $19^{\circ} 56^{\prime}$ and $20^{\circ} 07^{\prime} \mathrm{N}$, and meridians $102^{\circ} 07^{\prime}$ and $102^{\circ} 25^{\prime} \mathrm{W}$, at an altitude of $1580 \mathrm{~m}$. It borders North with Ixtlan and Ecuandureo municipalities; to the East with the municipalities of Ecuandureo, Tlazazalca, and Tangancicuaro; to the South with the municipalities of Tangancicuaro and Jacona; to the West with the municipalities of Jacona, Tangamandapio, Chavinda, and Ixtlan. It has an area of $335.55 \mathrm{~km}^{2}$, covering $0.56 \%$ of the state. It has a total population of 186,102 [7]. The weather is warm-subhumid with summer rains. It has an annual rainfall between 700 and $1000 \mathrm{~mm}$ and temperatures between 16 and $22{ }^{\circ} \mathrm{C}$ [7]. It is the third most populous city in the state. Zamora is one of the most important producers of blackberry and strawberry in the country; it has processing and packing companies, which export these products. Its geographical location sets the city as an important commercial and economic link between the capital of the state (Morelia) and the city of Guadalajara (the third most important in the country) [7]. Zamora is in the Sub-basin of Duero River, belonging to the Lerma Santiago hydrological region [8]. Figure 1 shows the location of the studied area and the selected sampling wells. 


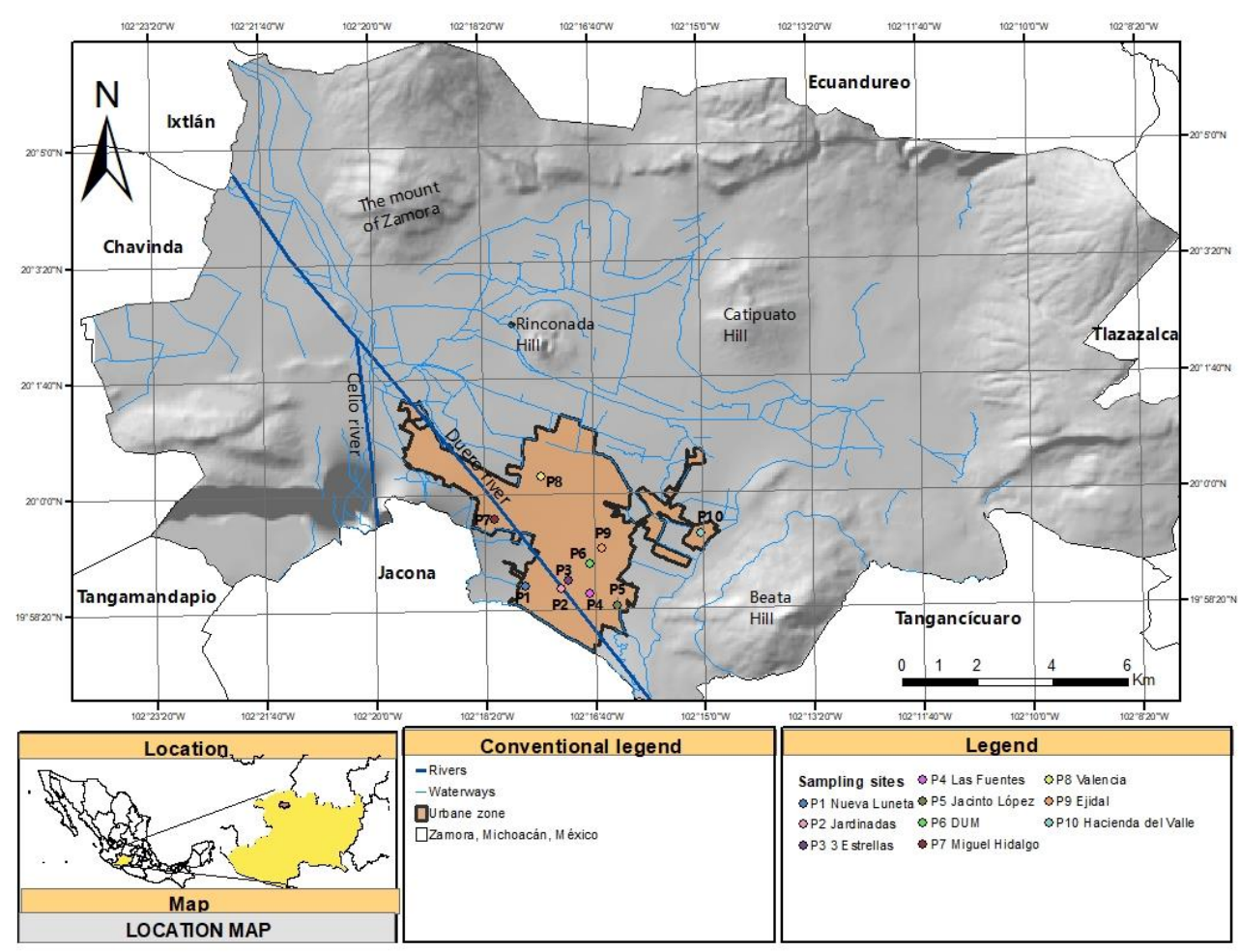

Figure 1. Location of the sampling sites in the urban area of Zamora, Mexico.

\subsection{Geology and Hydrogeology}

The studied area is located in the sub-province of "Area of Tectonic Pits", located at the northwestern part of Michoacán state (Figure 2), which is characterized by the alignment of its basins in an East-West direction.

This region has constant volcanic activity, reflected by many volcanic systems and extrusive rocks, made up mainly of basaltic and andesitic rocks [6].

The altitude ranges from 1530 to $1600 \mathrm{~m}$, located in an old lake basin, thicker than $300 \mathrm{~m}$; to the north, there are alignments due to the efforts exerted on the extrusive igneous rocks of andesitic composition that constitute the basement of the region [6].

The mountain range surrounding the Zamora Valley contains Quaternary basalts, underlying lower permeability volcanic rocks. They have high permeability and infiltration capacity due to their vesicular texture and fracturing; therefore, they are excellent recharge receptors and constitute permeable aquifers in the subsoil of the southern portion of the valley, where alluvial deposits cover them. In contrast, Tertiary basalts have lower infiltration and permeability capacity, because their structure is massive and poorly fractured. They have a staggered pattern because of tectonism and constitute the geohydrological basement of the aquifer. The primary aquifer in the valley consists of basaltic, pyroclastic, alluvial materials, and lake deposits; the first three are the most permeable elements; the others are aquitards of medium to low permeability. Its thickness increases from the edges towards the center of the valley, it is inferiorly limited by old lake deposits, and in the lower portions of the valley, it is semi-confined by recent lake deposits [6] (Table 1). 


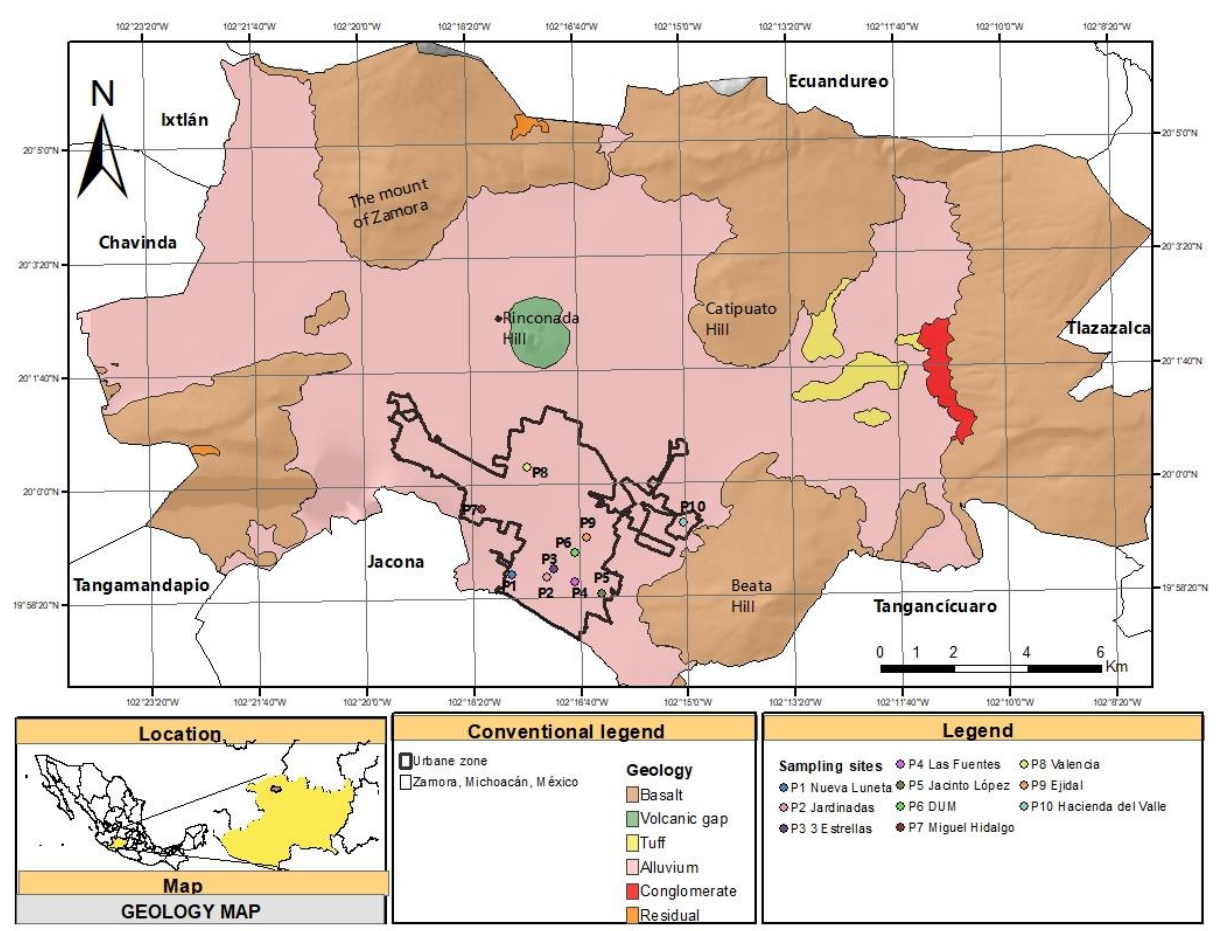

Figure 2. Geology in the urban area of Zamora, Mexico.

Table 1. Lithological column of Zamora Municipality, Michoacán.

\begin{tabular}{ccc}
\hline Layer & Depth $(\mathbf{m})$ & Lithological Description \\
\hline 1 & 1.5 & Clasts and rock fragments with scoria and clay sands, without saturation. \\
\hline 2 & 17 & $\begin{array}{r}\text { Deposits with swampy materials, with silts and clays, interacting with siliceous } \\
\text { sediments and fine granulometry clastic materials without saturation. }\end{array}$ \\
\hline 3 & 45 & Clastic material, rock pieces, scoria, and cineritic material, with sandy-clay sediments, \\
and low saturation.
\end{tabular}

\subsection{Sampling}

Ten representative sampling sites of the studied area were selected (Table 2), located in strategic areas such as growing areas, wells adjacent to the Duero River, sites with high population index, and areas with poor or no health infrastructure.

Two sampling campaigns were performed in May (dry season) and November (end of the rainy season) 2018.

Samples were taken to analyze physicochemical parameters, major ions, and trace elements. The sampling for physicochemical parameters was carried out in $2 \mathrm{~L}$ polyethylene bottles (HDPE) filled to minimize the presence of air to avoid chemical changes.

The trace elements samples were taken in $125 \mathrm{~mL}$ HDPE containers previously decontaminated with $\mathrm{HNO}_{3}$ and filled with deionized water [9]. In the field, one bottle was used as a control draining and refilling it with deionized water to obtain data concerning possible pollutants from sources different from water. A second bottle was emptied and filled with the sample. These containers were preserved with ultrapure $\mathrm{HNO}_{3}[9,10]$.

All samples were kept in refrigeration $\left(4^{\circ} \mathrm{C}\right)$ until the analysis indicated in the regulation. 
Table 2. Location and depth of the studied wells in the urban area of Zamora, Michoacán.

\begin{tabular}{ccc}
\hline Site & Coordinates & Depth (m) \\
\hline P1 & $19^{\circ} 58^{\prime} 40.5^{\prime \prime} \mathrm{N} 102^{\circ} 17^{\prime} 43.2^{\prime \prime} \mathrm{W}$ & 55 \\
P2 & $19^{\circ} 58^{\prime} 38.5^{\prime \prime} \mathrm{N} 102^{\circ} 17^{\prime} 10.7^{\prime \prime} \mathrm{W}$ & 40 \\
P3 & $19^{\circ} 58^{\prime} 44.7^{\prime \prime} \mathrm{N} 102^{\circ} 17^{\prime} 04.4^{\prime \prime} \mathrm{W}$ & 60 \\
P4 & $19^{\circ} 58^{\prime} 33.3^{\prime \prime} \mathrm{N} 102^{\circ} 16^{\prime} 44.4^{\prime \prime} \mathrm{W}$ & 90 \\
P5 & $19^{\circ} 58^{\prime} 23.2^{\prime \prime} \mathrm{N} 102^{\circ} 16^{\prime} 19.6^{\prime \prime} \mathrm{W}$ & 150 \\
P6 & $19^{\circ} 58^{\prime} 59.3^{\prime \prime} \mathrm{N} 102^{\circ} 16^{\prime} 44.0^{\prime \prime} \mathrm{W}$ & 150 \\
P7 & $19^{\circ} 59^{\prime} 38.4^{\prime \prime} \mathrm{N} 102^{\circ} 18^{\prime} 10.7^{\prime \prime} \mathrm{W}$ & 180 \\
P8 & $20^{\circ} 00^{\prime} 14.7^{\prime \prime} \mathrm{N} 102^{\circ} 17^{\prime} 28.0^{\prime \prime} \mathrm{W}$ & 120 \\
P9 & $1^{\circ} 59^{\prime} 12.2^{\prime \prime} \mathrm{N} 102^{\circ} 16^{\prime} 33.8^{\prime \prime} \mathrm{W}$ & 140 \\
P10 & $19^{\circ} 59^{\prime} 24.0^{\prime \prime} \mathrm{N} 102^{\circ} 15^{\prime} 02.5^{\prime \prime} \mathrm{W}$ & 130 \\
\hline
\end{tabular}

\subsection{Measurement Techniques}

Temperature $(\mathrm{T}), \mathrm{pH}$ and electrical conductivity were measured in situ, and total hardness, total alkalinity, $\mathrm{Ca}^{2+}, \mathrm{Mg}^{2+}, \mathrm{Na}^{+}, \mathrm{K}^{+}, \mathrm{Cl}^{-}, \mathrm{SO}_{4}{ }^{2-}, \mathrm{N}-\mathrm{NH}_{3}, \mathrm{HCO}_{3}{ }^{-}, \mathrm{CO}_{3}{ }^{2-}$, and trace elements $(\mathrm{Al}, \mathrm{Ba}$, $\mathrm{Cd}, \mathrm{Co}, \mathrm{Cr}, \mathrm{Cu}, \mathrm{Fe}, \mathrm{Mn}, \mathrm{Ni}, \mathrm{Pb}, \mathrm{Sb}, \mathrm{Tl}, \mathrm{V}, \mathrm{Zn}$ ) were determined in the laboratory.

Electrical conductivity and $\mathrm{pH}$ were measured in situ with a potentiometer (Thermo Scientific Orion Star A320), and the temperature was measured with an immersion thermometer [10].

Analytical techniques of potentiometry, volumetry, and atomic absorption spectrometry were used in the determination of the physicochemical parameters in the laboratory, following the recommendations of the Mexican regulations and the Standard Methods [10]. The trace elements analysis was performed by inductively coupled plasma mass spectrometry technique (ICP-MS). The quality of the chemical data was assessed by calculating ion balances (IB). All IB were found below $10 \%$; therefore, all samples were considered in the calculations of this work.

Geochemical methods were used to establish the processes controlling the groundwater chemistry: chemical speciation of trace elements was calculated, and Piper, Giggenbach, Schöller, Gibbs, and binary diagrams were built, in addition to Chloro Alkaline Indices.

\subsection{Water Quality Index}

The Groundwater Quality Index used in this work was developed by Brown et al. [11]. The method is used for the evaluation of groundwater quality worldwide due to the ability to express information on water quality. Moreover, it is one of the most effective tools for the evaluation and management of groundwater quality [12].

The procedure takes place in three stages. In the first stage an individual weight (wi) between 1 and 5 is assigned to 13 parameters ( $\mathrm{pH}$, Total Dissolved Solids (TDS), $\mathrm{Cl}^{-}, \mathrm{SO}_{4}{ }^{2-}, \mathrm{HCO}_{3}{ }^{-}, \mathrm{Ca}^{2+}$, $\mathrm{Mg}^{2+}, \mathrm{Na}^{+}, \mathrm{K}^{+}$, Total Hardness, $\mathrm{F}^{-}, \mathrm{NO}_{3}{ }^{-}$and $\mathrm{N}-\mathrm{NH}_{3}$ ) depending on its importance in the evaluation of water quality [3].

In the second stage, the relative weight $\left(W_{i}\right)$ of each parameter is calculated using Equation (1):

$$
W_{i}=\frac{w_{i}}{\sum_{i=1}^{n} w_{i}}
$$

where $W_{i}$ is the relative weight of each parameter, $w_{i}$ is the weight of each parameter, and $\mathrm{n}$ is the number of parameters. Table 3 indicates the values of $w_{i}$ and $W_{i}$.

Table 3. Weights and relative weights of the parameters to evaluate the water quality index.

\begin{tabular}{ccc}
\hline Parameter & Weight $\left(w_{\boldsymbol{i}}\right)$ & Relative Weight $\left(\boldsymbol{W}_{\boldsymbol{i}}\right)$ \\
\hline $\mathrm{pH}$ & 4 & 0.089 \\
$\mathrm{TDS}$ & 5 & 0.111 \\
$\mathrm{Cl}^{-}$ & 3 & 0.067 \\
\hline
\end{tabular}


Table 3. Cont.

\begin{tabular}{ccc}
\hline Parameter & Weight $\left(w_{i}\right)$ & Relative Weight $\left(W_{i}\right)$ \\
\hline $\mathrm{SO}_{4}{ }^{2-}$ & 5 & 0.111 \\
$\mathrm{Na}^{+}$ & 3 & 0.067 \\
$\mathrm{~K}^{+}$ & 2 & 0.044 \\
$\mathrm{HCO}_{3}{ }^{-}$ & 1 & 0.022 \\
$\mathrm{Ca}^{2+}$ & 3 & 0.067 \\
$\mathrm{Mg}^{2+}$ & 3 & 0.067 \\
$\mathrm{NO}_{3}{ }^{-}$ & 5 & 0.111 \\
$\mathrm{Hardness}$ & 4 & 0.089 \\
$\mathrm{~F}^{-}$ & 5 & 0.111 \\
$\mathrm{~N}^{-} \mathrm{NH}_{3}$ & 2 & 0.044 \\
$\mathrm{TOTAL}^{-}$ & 45 & 1 \\
\hline
\end{tabular}

In the third stage, the quality rating for each parameter is calculated from Equation (2):

$$
\mathrm{q}_{\mathrm{i}}=\left(\frac{\mathrm{C}_{\mathrm{i}}}{\mathrm{S}_{\mathrm{i}}}\right) 100
$$

where $q_{i}$ is the quality rating, $C_{i}$ is the concentration of each chemical parameter, $S_{i}$ is the concentration of the standards established by the Official Mexican Standard [13] and by World Health Organization (WHO). Table 4 shows the maximum permissible limits of Mexican and international regulations.

In the fourth stage, the sub-index of ith parameter $\left(\mathrm{SI}_{\mathrm{i}}\right)$ is calculated for each parameter using Equation (3):

$$
\mathrm{SI}_{\mathrm{i}}=\mathrm{W}_{\mathrm{i}} \mathrm{q}_{\mathrm{i}}
$$

where $\mathrm{SI}_{\mathrm{i}}$ is the sub-index of the ith parameter, $\mathrm{q}_{\mathrm{i}}$ is the quality rating, and $\mathrm{W}_{\mathrm{i}}$ is the relative weight.

Table 4. Maximum permissible limits of Mexican and international regulations. Concentrations are expressed in $\mathrm{mg} / \mathrm{L}$.

\begin{tabular}{ccc}
\hline Parameter & Mexican Regulation & WHO Regulation \\
\hline $\mathrm{pH}$ & $6.5-8.5$ & $6.5-8.5$ \\
$\mathrm{TDS}$ & 1000 & 1000 \\
$\mathrm{Cl}^{-}$ & 250 & 250 \\
$\mathrm{SO}_{4}^{2-}$ & 400 & 250 \\
$\mathrm{Na}^{+}$ & 200 & 200 \\
$\mathrm{~K}^{+}$ & - & 12 \\
$\mathrm{HCO}_{3}{ }^{-}$ & - & 120 \\
$\mathrm{Ca}^{2+}$ & - & 75 \\
$\mathrm{Mg}^{2+}$ & - & 50 \\
$\mathrm{NO}_{3}{ }^{-}$ & 10 & 45 \\
$\mathrm{Hardness}$ & 500 & 500 \\
$\mathrm{PO}_{4}{ }^{3-}$ & - & 10 \\
$\mathrm{~N}_{-} \mathrm{NH}_{3}$ & 0.5 & 1.5 \\
\hline
\end{tabular}

Finally, Water Quality Index (WQI) is obtained from Equation (4):

$$
\mathrm{WQI}=\sum \mathrm{S}_{\mathrm{i}}
$$

WQI values are classified into five categories (Table 5): excellent, good, fair, poor and unacceptable for human use [12]. 
Table 5. Classification of the Water Quality Index.

\begin{tabular}{cc}
\hline WQI & Water Quality \\
\hline$<50$ & Excellent \\
$50-100$ & Good \\
$100-200$ & Fair \\
$200-300$ & Poor \\
$>300$ & Unacceptable \\
\hline
\end{tabular}

\section{Results and Discussion}

\subsection{In Situ Parameters}

The water temperature showed values between $21^{\circ} \mathrm{C}$ and $37^{\circ} \mathrm{C}$. Although two wells exceeded $30{ }^{\circ} \mathrm{C}$, the water in this area is not considered to be thermal. The highest temperatures were observed in May in all wells within the spring season.

$\mathrm{pH}$ values ranged from 6.73 to 8.45 , showing an alkaline behavior due to water mineralization, probably coming from the salt content in the rock surrounding the aquifer. The highest values at all sites were observed in May, which corresponds to the end of the dry season. It can be assumed that in this season the concentration of salts that provide alkalinity to water was higher than that observed in November, which corresponds to the last month of the rainy season, in which the recharge of the aquifer allowed the dissolution of the ions, which can be confirmed with the reported concentrations, in particular, the presence of carbonates and bicarbonates.

The electrical conductivity shows the presence of dissolved salts in the water that are generally incorporated into the water from geochemical processes such as ion exchange, evaporation, silicate weathering, and the solubilization process that take place within the aquifers [14]. In this study, values between 311 and $957 \mu \mathrm{S} / \mathrm{cm}$ were observed. Most sites had the highest values in spring (May). Electrical conductivity is a parameter directly related to the presence of ions in dissolution, so the presence of dissolved salts can be observed in all sites. Table 6 shows the temperature, $\mathrm{pH}$, and electrical conductivity values observed in this study.

Table 6. Results of the parameters measured in situ in two sampling campaigns.

\begin{tabular}{ccccc}
\hline Site & Sampling Campaign & $\begin{array}{c}\text { Temperature } \\
\left({ }^{\circ} \mathbf{C}\right)\end{array}$ & $\mathbf{p H}$ & $\begin{array}{c}\text { Electrical Conductivity } \\
(\boldsymbol{\mu S} / \mathbf{c m})\end{array}$ \\
\hline \multirow{2}{*}{ P1 } & May 18 & 24 & 8 & 461 \\
& Nov 18 & 21 & 7.67 & 498.6 \\
\hline \multirow{2}{*}{ P2 } & May 18 & 25 & 7.6 & 608 \\
& Nov 18 & 23 & 7.52 & 743.9 \\
\hline \multirow{2}{*}{ P3 } & May 18 & 26 & 7.98 & 820 \\
& Nov 18 & 23 & 6.73 & 957.6 \\
\hline \multirow{2}{*}{ P4 } & May 18 & 31 & 8.31 & 428 \\
& Nov 18 & 27 & 7.63 & 495.3 \\
\hline \multirow{2}{*}{ P5 } & May 18 & 28 & 8.27 & 479 \\
& Nov 18 & 21 & 7.33 & 511.4 \\
\hline \multirow{2}{*}{ P6 } & May 18 & 37 & 8.45 & 394 \\
& Nov 18 & 24 & 7.85 & 386.5 \\
\hline \multirow{2}{*}{ P7 } & May 18 & 28 & 8.34 & 389 \\
& Nov 18 & 26 & 7.69 & 396.2 \\
\hline \multirow{2}{*}{ P8 } & May 18 & 29 & 8.08 & 412 \\
& Nov 18 & 24 & 7.43 & 418.2 \\
\hline
\end{tabular}


Table 6. Cont.

\begin{tabular}{ccccc}
\hline Site & Sampling Campaign & $\begin{array}{c}\text { Temperature } \\
\left({ }^{\circ} \mathbf{C}\right)\end{array}$ & $\mathbf{p H}$ & $\begin{array}{c}\text { Electrical Conductivity } \\
(\boldsymbol{\mu S} / \mathbf{c m})\end{array}$ \\
\hline \multirow{2}{*}{ P9 } & May 18 & 29 & 8.11 & 348 \\
& Nov 18 & 27 & 7.67 & 335.6 \\
\hline \multirow{2}{*}{ P10 } & May 18 & 27 & 8.32 & 311 \\
& Nov 18 & 22 & 7.78 & 343.6 \\
\hline \multirow{2}{*}{ NOM-127-SSA1-1994 } & - & - & $6.5-8.5$ & - \\
\hline USEPA & - & - & $6.5-8.5$ & - \\
\hline
\end{tabular}

\subsection{Physicochemical Parameters}

The turbidity and color values were under the limit recommended by the Mexican regulations (5 UTN and $20 \mathrm{Pt-Co}$ units, respectively); however, the turbidity exceeded the United States Environmental Protection Agency (USEPA) recommendation for drinking water at all sites (1 UTN). Turbidity values ranged from 1.35 to $4.6 \mathrm{UTN}$, while color was observed in a range of 5 to $10 \mathrm{Pt}-\mathrm{Co}$ units. Turbidity values were mostly higher at the end of the rainy season (November), probably due to the resuspension of solids during the aquifer recharge. The color showed no differences between both seasons.

Settable, suspended, dissolved, and total solids were analyzed, showing a more significant contribution of dissolved solids over the concentration of total solids. TDS represent different types of dissolved minerals. These vary considerably in different geological regions due to differences in mineral solubilities [15]. Mexican regulation recommends a maximum permissible limit in drinking water of dissolved solids of $1000 \mathrm{mg} / \mathrm{L}$ while the USEPA recommendation is $500 \mathrm{mg} / \mathrm{L}$ for this parameter. P3 site was the only one that exceeded the USEPA recommendation in both sampling campaigns. The total solids concentration ranged between $254 \mathrm{mg} / \mathrm{L}$ and $646 \mathrm{mg} / \mathrm{L}$. Most sites showed the highest concentrations of dissolved and total solids during the dry season.

A direct relationship between the concentration of dissolved solids and the value of the electrical conductivity of the water can be observed. Sites $\mathrm{P} 2$ and $\mathrm{P} 3$ show the highest presence of both parameters, while sites P9 and P10 have the lowest values, indicating the lowest presence of dissolved salts.

Alkalinity represents the presence of carbonate and bicarbonate salts in water [5]. This parameter has a direct relationship with hardness, which is usually mainly due to the presence of calcium and magnesium expressed as $\mathrm{CaCO}_{3}$. Other ions, such as iron or manganese, also contribute to this parameter $[16,17]$. The hardness value depends on $\mathrm{pH}$ and alkalinity values since the $\mathrm{pH}$ determines the dissolution capacity of the minerals in the water. In this study, the relationship between these three parameters can be seen, showing a similar behavior between hardness and alkalinity, so a carbonated type of hardness can be inferred. This relationship allows us to infer the majority presence of carbonate and bicarbonate salts mainly of calcium and, in a smaller concentration, magnesium, iron, and manganese in this studied area. The total hardness and alkalinity showed the lower concentrations slightly in the rainy season, probably due to the dilution.

The $\mathrm{BOD}_{5}$ values observed indicate that the water does not receive representative organic contamination. It was important to determine this parameter because some of the wells are in agricultural areas. The Mexican regulation does not make recommendations on the maximum permissible limit of this parameter; however, it is an important indicator of biodegradable organic contamination in water. The chemical oxygen demand (COD) values were similar to those of $\mathrm{BOD}_{5}$, so it can be inferred that there is no non-biodegradable biological contamination in this water, and the COD value corresponds to the biodegradable organic matter. Table 7 shows the concentration of the physicochemical parameters observed in this study. 
Table 7. Physicochemical parameters in the water samples from the 10 sites: turbidity (NTU), color (Pt/Co), and sedimentable, dissolved, suspended and total solids, total hardness, total alkalinity, chemical oxygen demand (COD) and biochemical oxygen demand (BOD $)_{5}$. Concentrations of solids, hardness, and alkalinity are expressed in $\mathrm{mg} / \mathrm{L}$. Concentrations of $\mathrm{COD}$ and $\mathrm{BOD}_{5}$ are expressed in $\mathrm{mg} \mathrm{O}_{2} / \mathrm{L}$.

\begin{tabular}{|c|c|c|c|c|c|c|c|c|c|c|c|}
\hline Site & $\begin{array}{c}\text { Sampling } \\
\text { Campaign (2018) }\end{array}$ & Turbidity & Color & $\begin{array}{l}\text { Sedimentable } \\
\text { Solids }\end{array}$ & $\begin{array}{l}\text { Dissolved } \\
\text { Solids }\end{array}$ & $\begin{array}{l}\text { Suspended } \\
\text { Solids }\end{array}$ & $\begin{array}{c}\text { Total } \\
\text { Solids }\end{array}$ & $\begin{array}{c}\text { Total } \\
\text { Hardness }\end{array}$ & $\begin{array}{c}\text { Total } \\
\text { Alkalinity }\end{array}$ & COD & BOD $_{5}$ \\
\hline \multirow{2}{*}{$\mathrm{P} 1$} & May & 1.4 & 5 & 0.1 & 378 & 4 & 382 & 193.8 & 181 & 5.4 & 3.5 \\
\hline & Nov & 4.6 & 10 & nd & 378 & 6 & 384 & 164 & 194 & 3 & 1.85 \\
\hline \multirow[b]{2}{*}{$\mathrm{P} 2$} & May & 1.66 & 5 & 0.1 & 496 & 4 & 500 & 238.08 & 243 & 4.7 & 3.2 \\
\hline & Nov & 2.4 & 5 & nd & 486 & 4 & 490 & 240 & 235 & 5.4 & 3.55 \\
\hline \multirow{2}{*}{ P3 } & May & 1.35 & 5 & nd & 644 & 2 & 646 & 325.56 & 312 & 4.7 & 3.17 \\
\hline & Nov & 2.4 & 5 & 0.1 & 608 & 4 & 612 & 320 & 300 & 4.8 & 3.2 \\
\hline \multirow{2}{*}{$\mathrm{P} 4$} & May & 1.41 & 5 & nd & 352 & 2 & 354 & 177.8 & 182 & 4.5 & 2.92 \\
\hline & Nov & 2.5 & 5 & nd & 310 & 4 & 314 & 140 & 158 & 10.5 & 6.55 \\
\hline \multirow{2}{*}{ P5 } & May & 1.5 & 5 & nd & 382 & 2 & 384 & 190.2 & 194 & 3.9 & 2.45 \\
\hline & Nov & 4.1 & 10 & nd & 378 & 2 & 380 & 200 & 187 & 3.4 & 2.24 \\
\hline \multirow{2}{*}{ P6 } & May & 2.4 & 5 & nd & 304 & 2 & 306 & 162.36 & 156 & 1.4 & 0.91 \\
\hline & Nov & 2.5 & 5 & nd & 280 & 4 & 284 & 130 & 135 & 5.3 & 3.54 \\
\hline \multirow{2}{*}{ P7 } & May & 2.5 & 5 & nd & 300 & 2 & 302 & 151.44 & 163 & 17.6 & 11.36 \\
\hline & Nov & 2.8 & 5 & nd & 304 & 4 & 308 & 136 & 151 & 5.8 & 3.89 \\
\hline \multirow{2}{*}{ P8 } & May & 3 & 10 & 0.1 & 322 & 6 & 328 & 165.08 & 169 & 19.2 & 12.5 \\
\hline & Nov & 3.9 & 10 & nd & 302 & 4 & 306 & 142 & 158 & 8.5 & 5.16 \\
\hline \multirow{2}{*}{ P9 } & May & 4 & 10 & 0.2 & 262 & 16 & 278 & 143.28 & 146 & 15.7 & 10.2 \\
\hline & Nov & 2.5 & 5 & nd & 252 & 2 & 254 & 120 & 124 & 5.5 & 3.5 \\
\hline \multirow{2}{*}{$\mathrm{P} 10$} & May & 2.3 & 5 & 0.1 & 256 & 2 & 258 & 132.36 & 138 & 10.1 & 6.25 \\
\hline & Nov & 3.6 & 5 & nd & 270 & 2 & 272 & 130 & 131 & 11.8 & 7.67 \\
\hline NOM-127-SSA1-1994 & - & 5 & 20 & - & 1000 & - & - & 500 & - & - & - \\
\hline USEPA & - & 1 & 15 & - & 500 & - & - & 500 & - & - & - \\
\hline
\end{tabular}




\subsection{Major Ions}

The COD values were similar to those of $\mathrm{BOD}_{5}$, so it can be inferred that there is no non-biodegradable biological contamination in this water, and the COD value corresponds to the biodegradable organic matter. Table 4 shows the concentration of the physicochemical parameters observed in this study.

Most of the substances dissolved in groundwater are in an ionic state. Some ions are almost always present, and their sum represents almost all the dissolved ions [18]. These major ions are $\mathrm{Ca}^{2+}$, $\mathrm{Mg}^{2+}, \mathrm{Na}^{+}, \mathrm{K}^{+}, \mathrm{CO}_{3}{ }^{2-}, \mathrm{HCO}_{3}{ }^{-}, \mathrm{SO}_{4}{ }^{2-}, \mathrm{Cl}^{-}$.

It was observed that the predominant cations in this study were calcium and sodium, with magnesium and potassium in lower concentrations. These four species were found present in all samples during both sampling campaigns.

$\mathrm{Ca}^{2+}$ is usually the main cation in most groundwater due to its widespread diffusion in igneous, sedimentary, and metamorphic rocks [19]. $\mathrm{Mg}^{2+}$, less abundant than $\mathrm{Ca}^{2+}$ in groundwater, comes from the dissolution of carbonate rock minerals, evaporites, dolomites, and the alteration of ferromagnesian silicates [20]. $\mathrm{Na}^{+}$salts are highly soluble and tend to remain in solution because precipitation reactions do not occur among them, as is the case with $\mathrm{Ca}^{2+}$. However, $\mathrm{Na}^{+}$can be adsorbed on clays with high cation exchange capacity and can be exchanged for $\mathrm{Ca}^{2+}$, causing a decrease in water hardness (natural softening) [21]. It is important to note that the highest concentrations of $\mathrm{Na}^{+}$were shown at sites near the Duero River and the agricultural area, which could mean a contribution of this element to the water, but without exceeding the limits established by Mexican regulations. The natural origin of $\mathrm{K}^{+}$in water is often a result of chemical weathering and the subsequent dissolution of minerals from nearby sedimentary rocks, as well as silicate and clay minerals [22].

In waters with $\mathrm{pH}$ close to 8.3 , such as most groundwater, the dominant carbonated species is $\mathrm{HCO}_{3}{ }^{-}$, while $\mathrm{CO}_{3}{ }^{2-}$ begins to form at higher values [1]. The predominant anion in this study was $\mathrm{HCO}_{3}{ }^{-}$, while no $\mathrm{CO}_{3}{ }^{2-}$ was observed at three sites.

No site exceeded the normativity recommendation regarding $\mathrm{SO}_{4}{ }^{2-}$ concentration, another important nutrient, considered to be a major anion in any type of water. All sites showed the presence of $\mathrm{SO}_{4}{ }^{2-}$ in both sampling campaigns, indicating the highest concentrations during the dry season at most points. This ion was the second predominant major anion.

The presence of phosphorus was observed in both samplings. The most abundant chemical form of this element in water is $\mathrm{PO}_{4}{ }^{3-}$, considered one of the primary nutrients in the water, and together with $\mathrm{HCO}_{3}{ }^{-}, \mathrm{Cl}^{-}$and $\mathrm{SO}_{4}{ }^{2-}$, it is one of the major anions that contribute to the ionic equilibrium of water along with the cation group.

Except for evaporites and rocks of marine origin, rocks usually have a low proportion of $\mathrm{Cl}^{-}$. Furthermore, this ion does not form low solubility salts, and it does not oxidize or reduce in groundwater, it is not significantly absorbed or becomes part of biochemical processes, properties that make it an ideal tracer [15].

${\mathrm{N}-\mathrm{NO}_{3}}^{-}$may be present in groundwater as a result of the dissolution of rocks containing them or due to the anthropogenic activity of the area [23]. The importance of the determination of $\mathrm{N}^{-\mathrm{NO}_{3}}{ }^{-}$and $\mathrm{N}-\mathrm{NH}_{3}$ is that they are some of the main indicators of ancient $\left(\mathrm{NO}_{3}{ }^{-}\right)$and recent $\left(\mathrm{N}-\mathrm{NH}_{3}\right)$ organic contamination, expressing the excellent oxidation in the water. Moreover, being very soluble and movable, both are the most common forms of nitrogen in groundwater [4]. $\mathrm{N}-\mathrm{NH}_{3}$ appears as a trace species in natural groundwater, increasing its concentration when the medium is strongly reducing. This compound is the final product of the reduction of nitrogenous organic or inorganic substances that are naturally incorporated into groundwater. On the other hand, since the presence of ammonium promotes microbial proliferation, its detection in significant concentration in water is considered a mark of recent contamination. In this study, it was observed that $\mathrm{N}^{-\mathrm{NO}_{3}}{ }^{-}$concentration remained below the limit recommended by both Mexican drinking water regulations and the USEPA of $10 \mathrm{mg} / \mathrm{L}$, while $\mathrm{N}-\mathrm{NH}_{3}$ exceeded the Mexican recommendation of $0.5 \mathrm{mg} / \mathrm{L}$ in three sites. No point exceeded the 
USEPA's recommendation for drinking water $(6 \mathrm{mg} / \mathrm{L})$. The sites with higher concentrations of $\mathrm{N}^{-\mathrm{NH}_{3}}$ are located near the growing area, which can also lead to a nitrogen contribution to water.

It is important to note that the highest concentrations of all ions were observed during the spring sampling campaign, which may be due to the rock mineralization process and dilution in the rainy season. The order of abundance of major ions in this study is $\mathrm{HCO}_{3}{ }^{-}>\mathrm{Ca}^{2+}>\mathrm{Na}^{+}>\mathrm{Mg}^{2+}>\mathrm{Cl}^{-}$ $\approx \mathrm{SO}_{4}{ }^{2-}>\mathrm{K}^{+}>\mathrm{CO}_{3}{ }^{2-}>\mathrm{PO}_{4}{ }^{3-} \approx \mathrm{N}_{-} \mathrm{NO}_{3}{ }^{-}>\mathrm{N}-\mathrm{NH}_{3}$. Table 8 shows the concentration of the major ion analyzed in this study, and Figures 3 and 4 show spatial distribution of these parameters in the study area.

\subsection{Trace Elements}

The presence of some trace elements was observed. $\mathrm{Mn}, \mathrm{Ba}, \mathrm{V}, \mathrm{Fe}, \mathrm{Sb}, \mathrm{Co}$, and As were found at all sites. Copper and aluminum concentrations were also observed in five sites. No element exceeded the recommendations of both Mexican and international regulations. All concentrations were found at least in one order of magnitude below the regulation recommendations for drinking water. $\mathrm{No} C \mathrm{r}, \mathrm{Ni}$, $\mathrm{Zn}, \mathrm{Cd}$, or $\mathrm{Pb}$ were found. Table 9 shows the concentration of the trace elements analyzed in this study.

The presence of as in groundwater may have different sources including hydrothermal volcanism, oxidation of sulfurous minerals, desorption from the mineral in response to increased $\mathrm{pH}$ or concentration due to evaporation. The limit set by the Mexican standards of $25 \mathrm{~g} / \mathrm{L}$ was exceeded in some sites.

Fe is a trace element present in most groundwater. It is an essential element in human nutrition [4]. All sites are within the limit established by the Mexican regulations of $300 \mu \mathrm{g} / \mathrm{L}$.

$\mathrm{Mn}$ is one of the most abundant metallic elements in natural water. It is present in igneous and metamorphic rocks as a minor constituent. $\mathrm{Mn}^{2+}$ salts have high solubility, but under aeration conditions, they are oxidized precipitating oxyhydroxides. The chemistry of the $\mathrm{Mn}$ is similar to that of the Fe. The highest concentration of this element was observed during the dry season at all collection sites, but the limit allowed by Mexican regulations of $150 \mathrm{~g} / \mathrm{L}$ was not exceeded.

Ba is not considered an essential element in human nutrition. On some levels can cause heart damage, nerves, and blood vessels, and can even cause death [4]. This element was observed in all sites, in concentrations under the Mexican and USEPA regulations of 700 and $2000 \mathrm{~g} / \mathrm{L}$, respectively.

$\mathrm{Al}$ constitutes approximately $8 \%$ of the Earth's crust. It exists in nature, forming different stable minerals such as silicates and oxides. It is usually found in the form of pure aluminum silicate or combined with other metals such as $\mathrm{Na}, \mathrm{K}, \mathrm{Fe}, \mathrm{Ca}$, and $\mathrm{Mg}$, but never as a free metal, such as potassium, sodium, or aluminum feldspars. This trace element was observed in three sampling sites. None of these sites exceeded the concentration indicated by the Mexican and USEPA regulations of $200 \mathrm{~g} / \mathrm{L}$.

Although $\mathrm{Sb}$ can be found free, it is generally in its mineral form, mainly as sulfides. The biogeochemical behavior of antimony is similar to that of arsenic and phosphorus. In recent years there has been an increase of this metalloid in the environment due to anthropogenic activities, mainly due to emissions from vehicles, smelters, and the burning of municipal waste. This element was found on all sites in both sampling campaigns, in concentrations below the indication of USEPA regulation of $10 \mathrm{~g} / \mathrm{L}$.

The chemical behavior of $\mathrm{Co}$ is similar to that of iron and nickel, both in the free and combined state. It is widely distributed in nature and is found in $\mathrm{Fe}, \mathrm{Ni}, \mathrm{Cu}, \mathrm{Ag}, \mathrm{Mn}$, and $\mathrm{Zn}$ ores. Its main minerals are arsenides, oxides, and sulfides. It is also present in air, water, soil, plants, and animals. This metal can also be in the air and water and deposited on the soil through wind and dust. This element was observed in all sites. There is no water regulation on this element. 
Table 8. Major ions in the water samples from the 10 sites expressed in $\mathrm{mg} / \mathrm{L}$ : calcium $\left(\mathrm{Ca}^{2+}\right)$, magnesium $\left(\mathrm{Mg}^{2+}\right)$, sodium $\left(\mathrm{Na}^{+}\right)$, potassium $\left(\mathrm{K}^{+}\right)$, acid carbonate $\left(\mathrm{HCO}_{3}{ }^{-}\right)$, carbonate $\left(\mathrm{CO}_{3}{ }^{2-}\right)$, sulfate $\left(\mathrm{SO}_{4}{ }^{2-}\right)$, phosphate $\left(\mathrm{PO}_{4}{ }^{3-}\right)$, chloride $\left(\mathrm{Cl}^{-}\right)$, nitrate $\left({\mathrm{N}-\mathrm{NO}_{3}}^{-}\right)$, ammoniacal nitrogen $\left(\mathrm{N}-\mathrm{NH}{ }_{3}\right)$, and the ionic balance $(\%)$.

\begin{tabular}{|c|c|c|c|c|c|c|c|c|c|c|c|c|c|}
\hline Site & $\begin{array}{c}\text { Sampling } \\
\text { Campaign (2018) }\end{array}$ & $\mathrm{Ca}^{2+}$ & $\mathrm{Mg}^{2+}$ & $\mathrm{Na}^{+}$ & $\mathrm{K}^{+}$ & $\mathrm{HCO}_{3}{ }^{-}$ & $\mathrm{CO}_{3}{ }^{2-}$ & $\mathrm{SO}_{4}{ }^{2-}$ & $\mathrm{PO}_{4}{ }^{3-}$ & $\mathrm{Cl}^{-}$ & $\mathrm{N}-\mathrm{NO}_{3}{ }^{-}$ & $\mathrm{N}-\mathrm{NH}_{3}$ & $\begin{array}{c}\text { Ionic } \\
\text { Balance }\end{array}$ \\
\hline \multirow{2}{*}{ P1 } & May & 68.58 & 5.47 & 27.60 & - & 173.00 & 45.90 & 45.90 & 0.0587 & 32.14 & 0.076 & 0.3578 & 4 \\
\hline & Nov & 36.00 & 18.00 & 41.86 & 12.10 & 184.00 & 12.00 & 41.73 & 0.027 & 31.41 & 0.1514 & 0.2452 & 2.2 \\
\hline \multirow{2}{*}{$\mathrm{P} 2$} & May & 72.70 & 13.62 & 44.85 & - & 283.00 & 62.86 & 62.86 & 0.0771 & 44.63 & 0.765 & 0.1193 & 3.9 \\
\hline & Nov & 59.60 & 23.35 & 41.63 & 16.96 & 225.00 & 10.00 & 50.63 & 0.139 & 42.82 & 1.1985 & 0.0613 & 5.9 \\
\hline \multirow{2}{*}{ P3 } & May & 118.02 & 7.42 & 52.44 & - & 312.00 & 85.12 & 85.12 & 0.103 & 61.23 & 1.133 & 0.0596 & 3.6 \\
\hline & Nov & 70.40 & 35.02 & 48.30 & 21.00 & 300.00 & $<\mathrm{LD}$ & 79.48 & 0.011 & 61.26 & 1.7642 & 0.226 & 3.8 \\
\hline \multirow{2}{*}{$\mathrm{P} 4$} & May & 49.92 & 12.89 & 26.45 & - & 176.00 & 35.50 & 35.50 & 0.1079 & 27.28 & 0.061 & 0.4175 & 5.5 \\
\hline & Nov & 15.20 & 12.65 & 33.81 & 16.97 & 142.00 & 16.00 & 32.33 & 0.068 & 23.4 & 0.0228 & 0.4905 & 6.2 \\
\hline \multirow{2}{*}{ P5 } & May & 54.29 & 12.52 & 34.96 & - & 190.00 & 46.68 & 46.68 & 0.0862 & 34.18 & 0.058 & 0.1789 & 4.2 \\
\hline & Nov & 44.00 & 21.89 & 25.53 & 14.90 & 187.00 & $<\mathrm{LD}$ & 46.95 & 0.061 & 33.32 & 0.0237 & 0.3066 & 4.8 \\
\hline \multirow{2}{*}{ P6 } & May & 46.53 & 11.19 & 19.55 & - & 146.00 & 29.91 & 29.91 & 0.1019 & 22.81 & 0.04 & 0.0596 & 6.1 \\
\hline & Nov & 37.60 & 8.76 & 28.98 & 16.39 & 121.00 & 14.00 & 29.90 & 0.048 & 23.37 & 0.0938 & 0.0613 & 6.8 \\
\hline \multirow{2}{*}{ P7 } & May & 46.22 & 8.76 & 25.76 & - & 159.00 & 28.52 & 28.52 & 0.0447 & 25.3 & 0.05 & 4.473 & 5 \\
\hline & Nov & 36.80 & 10.70 & 32.20 & 13.00 & 143.00 & 8.00 & 31.34 & 0.086 & 25.4 & 0.0282 & 4.1376 & 5.5 \\
\hline \multirow{2}{*}{ P8 } & May & 51.98 & 8.51 & 22.31 & - & 169.00 & 32.95 & 32.95 & 0.2221 & 25.27 & 0.039 & 4.244 & 4.9 \\
\hline & Nov & 44.00 & 7.78 & 32.20 & 13.00 & 158.00 & $<\mathrm{LD}$ & 35.26 & 0.334 & 26.93 & 0.0237 & 4.1376 & 5.7 \\
\hline \multirow{2}{*}{ P9 } & May & 43.77 & 8.27 & 17.71 & - & 142.00 & 27.05 & 27.05 & 0.1593 & 18.85 & 0.025 & 1.113 & 5.3 \\
\hline & Nov & 36.00 & 7.30 & 22.08 & 12.40 & 110.00 & 14.00 & 26.95 & 0.071 & 15.42 & 0.0335 & 0.7358 & 5.9 \\
\hline \multirow{2}{*}{ P10 } & May & 43.74 & 10.46 & 17.71 & - & 134.00 & 24.94 & 24.94 & 0.116 & 17.36 & 1.066 & 0.119 & 9.3 \\
\hline & Nov & 33.60 & 11.19 & 23.46 & 11.65 & 117.00 & 14.00 & 27.70 & 0.099 & 21.41 & 1.0372 & 0.0613 & 3.7 \\
\hline NOM-127-SSA1-1994 & - & - & - & 200 & - & - & - & 400 & - & 250 & 10 & 0.5 & - \\
\hline USEPA & - & - & - & - & - & - & - & 250 & - & 250 & 10 & 6 & - \\
\hline
\end{tabular}




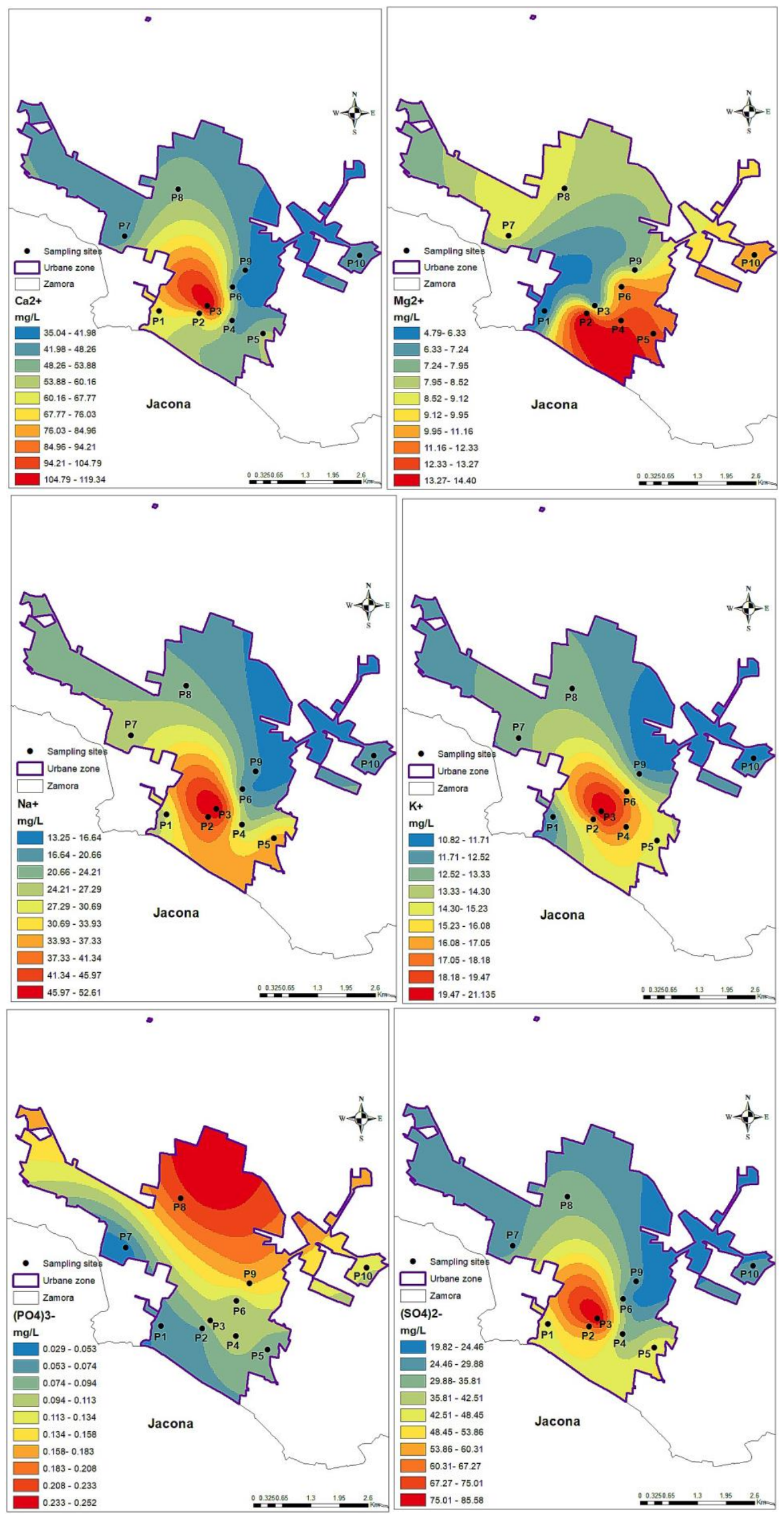

Figure 3. Distribution of the major ions content (mg/L): $\mathrm{Ca}^{2+}, \mathrm{Mg}^{2+}, \mathrm{Na}^{+}, \mathrm{K}^{+}, \mathrm{PO}_{4}{ }^{3-}$, and $\mathrm{SO}_{4}{ }^{2-}$ in the studied zone. 


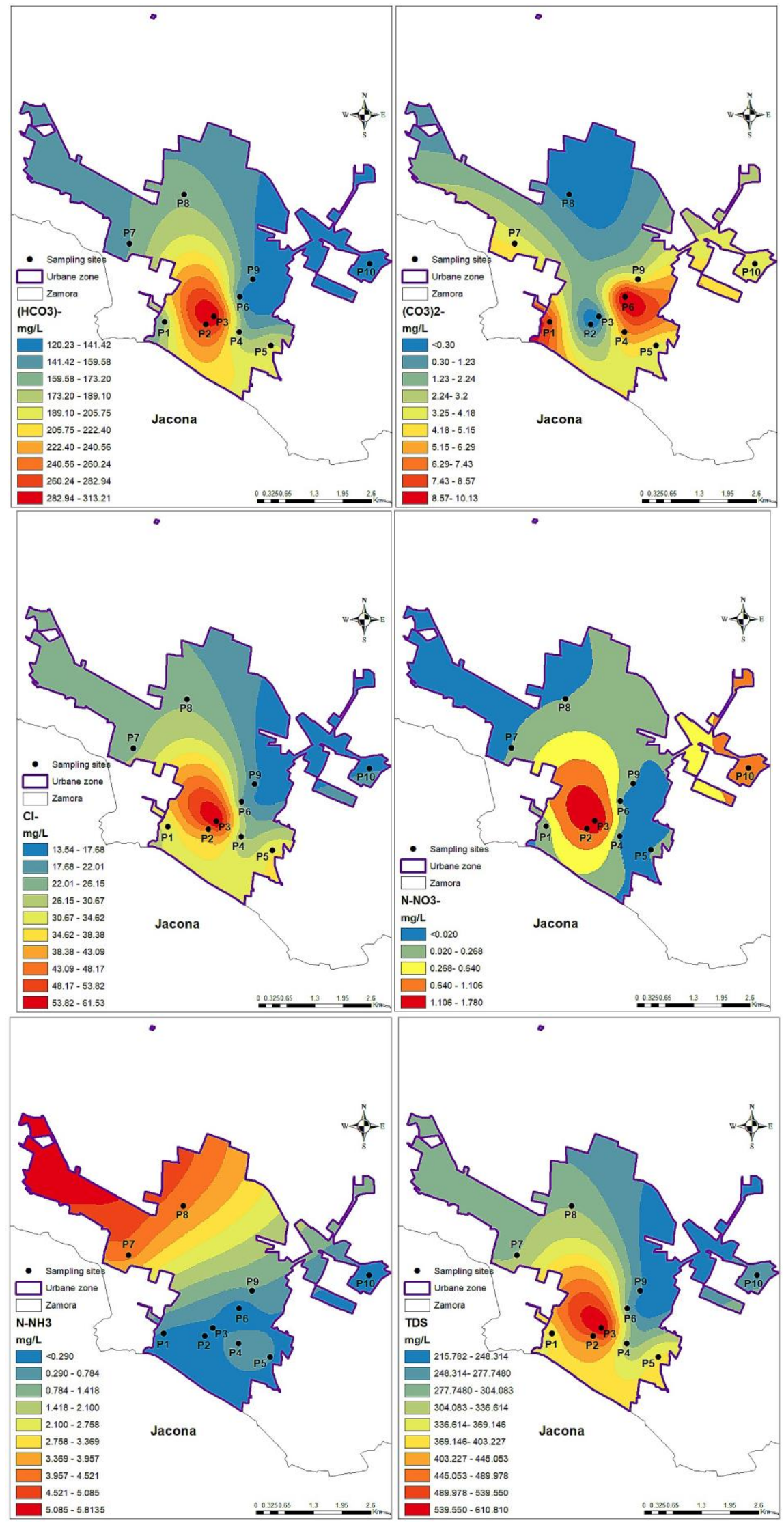

Figure 4. Distribution of the major ions content (mg/L): $\mathrm{HCO}_{3}{ }^{-}, \mathrm{CO}_{3}{ }^{2-}, \mathrm{Cl}^{-}, \mathrm{N}-\mathrm{NO}_{3}{ }^{-}, \mathrm{N}-\mathrm{NH}_{3}$, and TDS in the studied zone. 
Table 9. Concentrations of trace elements in the water samples from the 10 sites (g/L): arsenic (As), iron (Fe), manganese (Mn), barium (Ba), aluminum (Al), antimony $(\mathrm{Sb})$, cobalt $(\mathrm{Co})$, vanadium $(\mathrm{V})$, and copper $(\mathrm{Cu})$.

\begin{tabular}{|c|c|c|c|c|c|c|c|c|c|c|}
\hline Site & $\begin{array}{c}\text { Sampling } \\
\text { Campaign (2018) }\end{array}$ & $\begin{array}{c}\text { As } \\
(\mu \mathrm{g} / \mathrm{L})\end{array}$ & $\begin{array}{c}\mathrm{Fe} \\
(\mu \mathrm{g} / \mathrm{L})\end{array}$ & $\begin{array}{c}\mathrm{Mn} \\
(\mu \mathrm{g} / \mathrm{L})\end{array}$ & $\begin{array}{c}\mathrm{Ba} \\
(\mu \mathrm{g} / \mathrm{L})\end{array}$ & $\begin{array}{c}\mathrm{Al} \\
(\mu \mathrm{g} / \mathrm{L})\end{array}$ & $\begin{array}{c}\mathrm{Sb} \\
(\mu \mathrm{g} / \mathrm{L})\end{array}$ & $\begin{array}{c}\text { Co } \\
(\mu \mathrm{g} / \mathrm{L})\end{array}$ & $\begin{array}{c}\mathrm{V} \\
(\mu \mathrm{g} / \mathrm{L})\end{array}$ & $\begin{array}{c}\mathrm{Cu} \\
(\mu \mathrm{g} / \mathrm{L})\end{array}$ \\
\hline \multirow[b]{2}{*}{ P1 } & May & 0.392 & 2.930 & 0.937 & 13.807 & $<\mathrm{L} / \mathrm{D}$ & 1.175 & 0.015 & 0.393 & $<\mathrm{L} / \mathrm{D}$ \\
\hline & Nov & 0.137 & 154.970 & 15.648 & 28.514 & $<\mathrm{L} / \mathrm{D}$ & 0.499 & 0.016 & 0.301 & $<\mathrm{L} / \mathrm{D}$ \\
\hline \multirow{2}{*}{ P2 } & May & 0.780 & 1.589 & 28.894 & 36.710 & $<\mathrm{L} / \mathrm{D}$ & 1.166 & 0.154 & 4.274 & $<\mathrm{L} / \mathrm{D}$ \\
\hline & Nov & 0.658 & 58.415 & 74.198 & 77.725 & $<\mathrm{L} / \mathrm{D}$ & 0.586 & 0.153 & 6.884 & $<\mathrm{L} / \mathrm{D}$ \\
\hline \multirow{2}{*}{ P3 } & May & 0.184 & $<\mathrm{L} / \mathrm{D}$ & 22.816 & 61.797 & $<\mathrm{L} / \mathrm{D}$ & 0.648 & 0.424 & 9.005 & 0.565 \\
\hline & Nov & 1.157 & 2.474 & 59.800 & 125.462 & $<\mathrm{L} / \mathrm{D}$ & 0.602 & 0.446 & 11.333 & 0.933 \\
\hline \multirow{2}{*}{$\mathrm{P} 4$} & May & 0.059 & 28.172 & 7.865 & 6.992 & $<\mathrm{L} / \mathrm{D}$ & 0.424 & 0.007 & 0.365 & $<\mathrm{L} / \mathrm{D}$ \\
\hline & Nov & 0.321 & 28.554 & 19.775 & 13.340 & $<\mathrm{L} / \mathrm{D}$ & 0.427 & $<$ L.D. & 0.395 & $<\mathrm{L} / \mathrm{D}$ \\
\hline \multirow{2}{*}{ P5 } & May & 0.140 & 3.061 & 33.435 & 13.992 & $<\mathrm{L} / \mathrm{D}$ & 0.463 & 0.010 & 0.169 & $<\mathrm{L} / \mathrm{D}$ \\
\hline & Nov & 0.032 & 232.026 & 87.275 & 28.834 & $<\mathrm{L} / \mathrm{D}$ & 0.429 & 0.017 & 0.044 & $<\mathrm{L} / \mathrm{D}$ \\
\hline \multirow{2}{*}{ P6 } & May & 0.245 & 13.191 & 1.929 & 9.716 & $<\mathrm{L} / \mathrm{D}$ & 0.365 & 0.034 & 0.850 & $<\mathrm{L} / \mathrm{D}$ \\
\hline & Nov & 0.184 & 46.762 & 18.826 & 10.734 & $<\mathrm{L} / \mathrm{D}$ & 0.484 & 0.030 & 0.590 & $<\mathrm{L} / \mathrm{D}$ \\
\hline \multirow{2}{*}{ P7 } & May & 0.096 & 115.330 & 0.382 & 8.793 & $<\mathrm{L} / \mathrm{D}$ & 0.370 & 0.027 & 0.023 & $<\mathrm{L} / \mathrm{D}$ \\
\hline & Nov & 0.078 & 123.732 & 32.952 & 17.683 & $<\mathrm{L} / \mathrm{D}$ & 0.491 & 0.046 & 0.034 & 2.196 \\
\hline \multirow{2}{*}{ P8 } & May & 0.178 & 80.422 & 10.285 & 7.497 & $<\mathrm{L} / \mathrm{D}$ & 0.337 & 0.083 & 0.223 & $<\mathrm{L} / \mathrm{D}$ \\
\hline & Nov & 0.234 & 186.653 & 30.319 & 21.003 & 0.4847 & 0.476 & 0.102 & 0.181 & 19.882 \\
\hline \multirow{2}{*}{ P9 } & May & 0.215 & $<\mathrm{L} / \mathrm{D}$ & 16.729 & 9.152 & 1.244 & 0.438 & 0.024 & 1.686 & 18.141 \\
\hline & Nov & 0.289 & 68.328 & 35.529 & 12.273 & 1.8238 & 0.376 & 0.015 & 0.071 & 17.420 \\
\hline \multirow{2}{*}{ P10 } & May & 0.598 & $<\mathrm{L} / \mathrm{D}$ & $<\mathrm{L} / \mathrm{D}$ & 5.668 & $<\mathrm{L} / \mathrm{D}$ & 0.516 & $<\mathrm{L} / \mathrm{D}$ & 6.555 & 0.522 \\
\hline & Nov & 1.244 & 101.523 & 0.404 & 17.157 & 122.747 & 0.489 & 0.033 & 9.958 & 1.564 \\
\hline Detection limit & - & 0.0449 & 1.075 & 0.011 & 0.1134 & 0.04722 & 0.0057 & 0.0015 & 0.0056 & 0.021 \\
\hline NOM-127-SSA1-1994 & - & 25 & 300 & 150 & 700 & 200 & - & - & - & 2000 \\
\hline USEPA & - & 10 & 300 & 50 & 2000 & 200 & 10 & - & - & 1000 \\
\hline
\end{tabular}

$*<\mathrm{LD}=$ lower than the detection limit of the equipment. 
$\mathrm{V}$ is a trace element that accumulates in humans due to the intake of wheat, soy, or olive oil, but despite being essential, when ingested in concentrations higher than those required can cause health effects. This metal was found in all sites. There are no Mexican or USEPA regulations for this element.

$\mathrm{Cu}$ is an essential nutrient for humans. Drinking water usually contains less than $0.1 \mathrm{mg} / \mathrm{L}$. However, some groundwater may have higher concentrations of this metal since it is an element naturally found in rocks and soil. Its presence was observed only in five sampling sites, with a concentration below the Mexican and USEPA regulations of 2000 and $1000 \mathrm{~g} / \mathrm{L}$, respectively.

\subsection{Chemical Speciation of Trace Elements}

The study of the speciation or chemical mobility of the elements is essential for understanding and predicting the behavior and the impact they may have on any environmental system. The chemical mobility of a metal depends on its oxidation state, $\mathrm{pH}$, and redox potential, as well as its interactions with other components of the system [24]. The chemical speciation was calculated with the Visual MINTEQ program (version 3.1). This paper reports the chemical speciation of As, Fe, Mn, Ba, and V, elements found in significant concentration.

\subsubsection{Arsenic}

Arsenic is found in natural water as dissolved species As (III) or As (V), As (III) being the most labile and biotoxic state. As (V) is usually found as $\mathrm{H}_{2} \mathrm{AsO}_{4}{ }^{-}, \mathrm{HAsO}_{4}{ }^{2-} \mathrm{y} \mathrm{AsO}_{4}{ }^{3-}$, while As (III) is found as $\mathrm{H}_{4} \mathrm{AsO}_{3}{ }^{+}, \mathrm{H}_{2} \mathrm{AsO}_{3}{ }^{-}, \mathrm{HAsO}_{3}{ }^{2-}$. Arsenic is easily mobilized in the $\mathrm{pH}$ values typical of groundwater, from 6.5 to 8.5 [4]. The chemical form of As in the studied sites was predominantly $\mathrm{HAsO}_{4}{ }^{2-}$ (about $85 \%$ ) and in a smaller proportion $\mathrm{H}_{2} \mathrm{AsO}_{4}{ }^{-}$. According to Salcedo et al. [4], these chemical forms of As (V) usually predominate in the $\mathrm{pH}$ range observed in this study (6.7 to 8.4) and positive values of redox potential. An oxidizing system is inferred.

\subsubsection{Iron}

Fe is usually found in groundwater in the form of $\mathrm{Fe}^{2+}$, although it can be presented as $\mathrm{Fe}^{3+}$, $\mathrm{FeOH}^{2+}$, or $\mathrm{FeOH}^{+}$, depending on $\mathrm{pH}$, oxygen content, and chemical interaction with other elements [1]. At $\mathrm{pH}$ values of 4.5 to 9 , soluble $\mathrm{Fe}$ is usually in a ferrous state, especially if the medium is reducing as in most groundwater. Fe oxidizes under the action of air or by contact with chlorine, going into the ferric state and can thus be hydrolyzed to give an insoluble iron hydroxide [25]. In this study, $\mathrm{Fe}(\mathrm{OH})_{2}{ }^{+}$ presence is observed as a predominant species (about $80 \%$ ) in most of the studied sites. $\mathrm{Fe}(\mathrm{OH})_{4}{ }^{-}$and $\mathrm{Fe}(\mathrm{OH})_{3(\mathrm{aq})}$ were also observed in smaller proportions as expected, according to the $\mathrm{pH}$ values of this study. $\mathrm{Fe}(\mathrm{OH})_{4}{ }^{-}$species showed a more significant presence in sites with $\mathrm{pH}$ around 8.5 and positive redox potential.

\subsubsection{Manganese}

Mn can be found in groundwater as free ion $\mathrm{Mn}^{2+}$ or as $\mathrm{MnHCO}_{3}{ }^{+}$. It is often found in concentrations lower than Fe. Manganese salts are generally more soluble in acidic solutions than in alkaline solutions. In this study, $\mathrm{Mn}$ was found mainly as $\mathrm{Mn}^{2+}$ (about $86 \%$ ) and forming $\mathrm{MnCO}_{3(\mathrm{aq})}$ (about $8 \%$ ). $\mathrm{MnCO}_{3(\mathrm{aq})}$ was found in higher concentrations at sites with $\mathrm{pH}$ values close to 8 and with higher carbonate content. In a smaller proportion, $\mathrm{MnCO}_{3(\mathrm{aq})}, \mathrm{MnSO}_{4(\mathrm{aq})}$, and $\mathrm{MnHCO}_{3}{ }^{+}$complex were also observed in all sites.

\subsubsection{Barium}

The main sources of $\mathrm{Ba}$ in the water are the erosion of natural deposits, runoff in crop areas, or industrial wastewater. Barium is also found in limestones, sandstones, and occasionally in soils. The concentration of this element in groundwater comes mainly from the dissolution of barite $\left(\mathrm{BaSO}_{4}\right)$, increasing in reducing environments. It is usually found in groundwater in the form of $\mathrm{Ba}^{2+}[26]$. 
In this study, as expected, this metal was observed mainly as $\mathrm{Ba}^{2+}$ (around $95 \%$ ), followed by $\mathrm{BaSO}_{4(\mathrm{aq})}$ (around 2.3\%) and $\mathrm{BaHCO}_{3(\mathrm{aq})}$ (around 2.3\%).

\subsubsection{Vanadium}

$\mathrm{V}$ is an abundant element in the earth's crust that is forming minerals with other elements. Its chemical mobility increases under oxidizing and alkaline conditions $[27,28]$. It can occur with different oxidation states, with $\mathrm{V}(\mathrm{II})$ being the least stable in the environment. V(III) is more stable than $\mathrm{V}(\mathrm{II})$, but it also gradually oxidizes in the presence of air or dissolved oxygen, with $\mathrm{V}(\mathrm{V})$ being the predominant form in water exposed to atmospheric oxygen, while $\mathrm{V}(\mathrm{IV})$ can become predominant in reducing environments [29]. It was observed in the studied area that this element was found as $\mathrm{VOH}^{2+}$ (almost $100 \%$ in P4 to P7 and P9, P10), and as $\mathrm{V}(\mathrm{OH})_{2}{ }^{+}$(almost $100 \%$ in P1 to P3 and P8); being $\mathrm{V}(\mathrm{III})$ the expected chemical species according to the $\mathrm{pH}$ range found and to the absence of oxygen in groundwater.

\subsection{Hydrogeochemistry}

\subsubsection{Hydrochemical Facies}

Piper diagram is a useful tool to identify different hydrochemical facies or origins of groundwater by plotting the content of cations and major anions in groundwater, indicating the origin, source of dissolved salts and processes that affect the characteristics of these natural waters [18,22] The hydrochemical diagram was constructed using AquaChem 2014.2 software. Figure 5 shows the types of water in all studied sites. A bicarbonated-calcic water type $\left(\mathrm{Ca}^{2+}-\mathrm{HCO}_{3}{ }^{-}\right)$was observed in all samples, indicating that all sites belong to the same aquifer. This type of water is characterized by a low mineralization, low alkalinity, and short residence time in the aquifer.

The groundwater with the shortest residence time in the aquifer is generally bicarbonated, then it is sulfated, and the water with the highest permanence is chlorinated. This evolution is called the Chevotareb sequence. In the cationic composition, the analogous sequence would be: $\mathrm{Ca}^{2+}$ with the shortest residence time, then $\mathrm{Mg}^{2+}$, and finally $\mathrm{Na}^{+}$with the highest residence time in the aquifer.

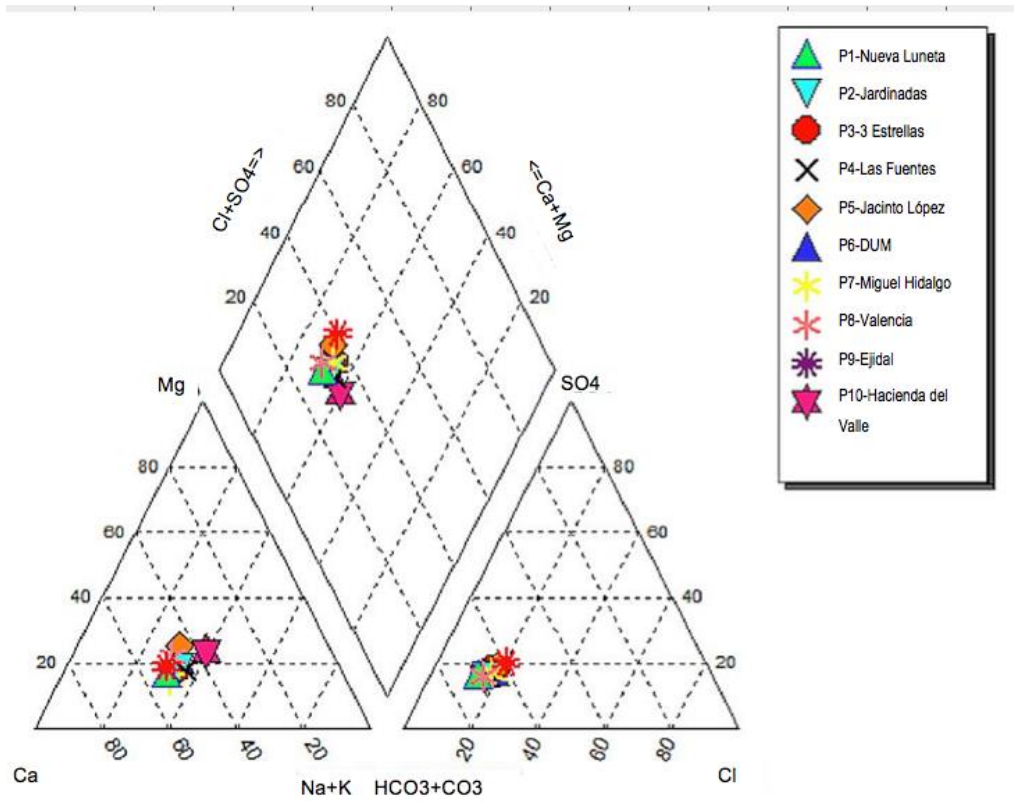

Figure 5. Piper diagram of the studied sites. 


\subsubsection{Hydrochemical Diagrams}

Hydrogeochemical diagrams are a graphical representation of the chemical characteristics of groundwater [30]. AquaChem 2014.2 software was used in the construction of these diagrams.

Figure 6 shows the location of the sampling sites in the Giggenbach triangular diagram. This scheme shows that all samples were in the immature water area, one of the main properties of cold groundwater. This type of water is characterized by not reaching equilibrium, i.e., they have a no chemical equilibrium with respect to the aquifer rock, where dissolution dominates when mixed with groundwater, and ionic exchange occurs [31]. According to Giggenbach [32], immature waters are inadequate for the evaluation of equilibrium temperatures. This result confirms that the chemical composition of groundwater is mainly controlled by the chemical dissolution of the rock [18].

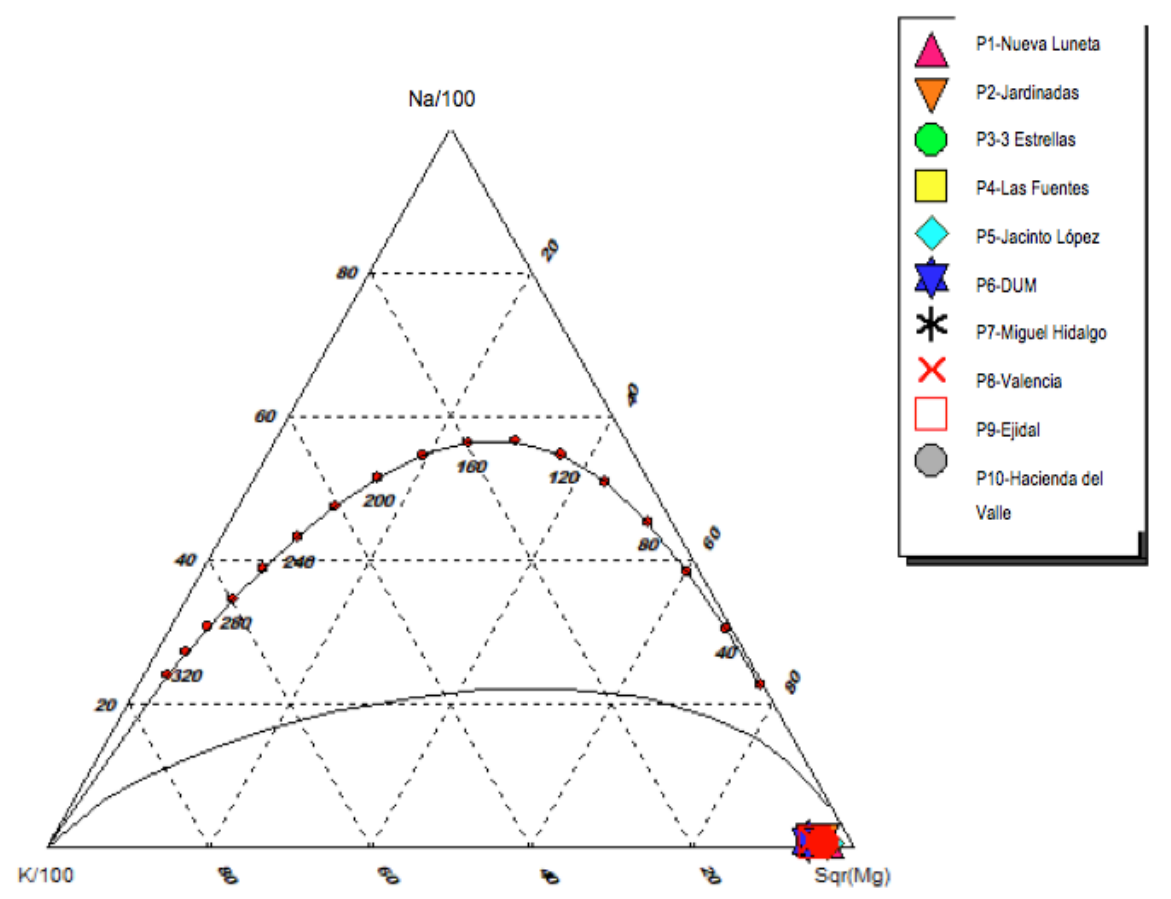

Figure 6. Giggenbach diagram of the studied sites.

The Schöeller diagram shows the absolute value of each major ion and identifies the highest concentrations [23]. Figure 7 presents this diagram, which shows $\mathrm{Ca}^{2+}$ as the dominant cation, while the dominant anion is $\mathrm{HCO}_{3}{ }^{-}$, confirming the information obtained in the diagrams above.

The evaporation rate, the chemical composition of the rock, and the rainwater generally control the chemistry of the groundwater [33]. The Gibbs diagram shows the mechanisms that control the chemistry of groundwater from the relationship of chemical components with their respective lithologies in the aquifer [34], representing the domain of precipitation, of evaporation and the water-rock interaction [35].

This diagram is useful for assessing the geological origin of chemical constituents in groundwater samples [36], where the concentration of TDS is plotted against a ratio of cation and anion concentration. Figures 8 and 9 show that the domain of water-rock interaction controls the chemistry of groundwater in the studied area, where the main process that affects the chemistry of water is the dissolution of carbonates and silicates. This process of water-rock interaction includes the chemical weathering of rocks, the dissolution-precipitation of secondary carbonates, and the ionic exchange between water and clay minerals in the area. 


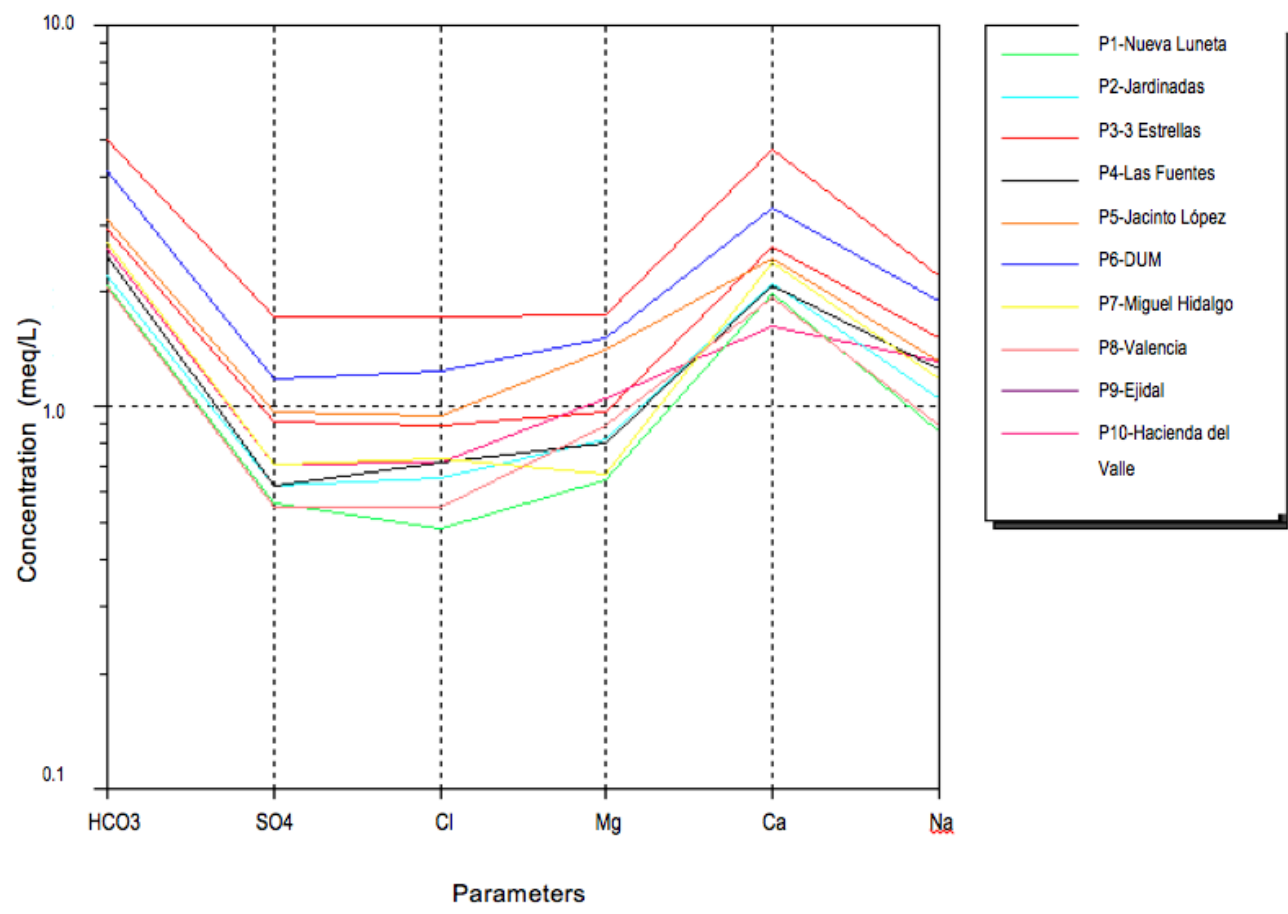

Figure 7. Schöeller diagram of the studied sites.

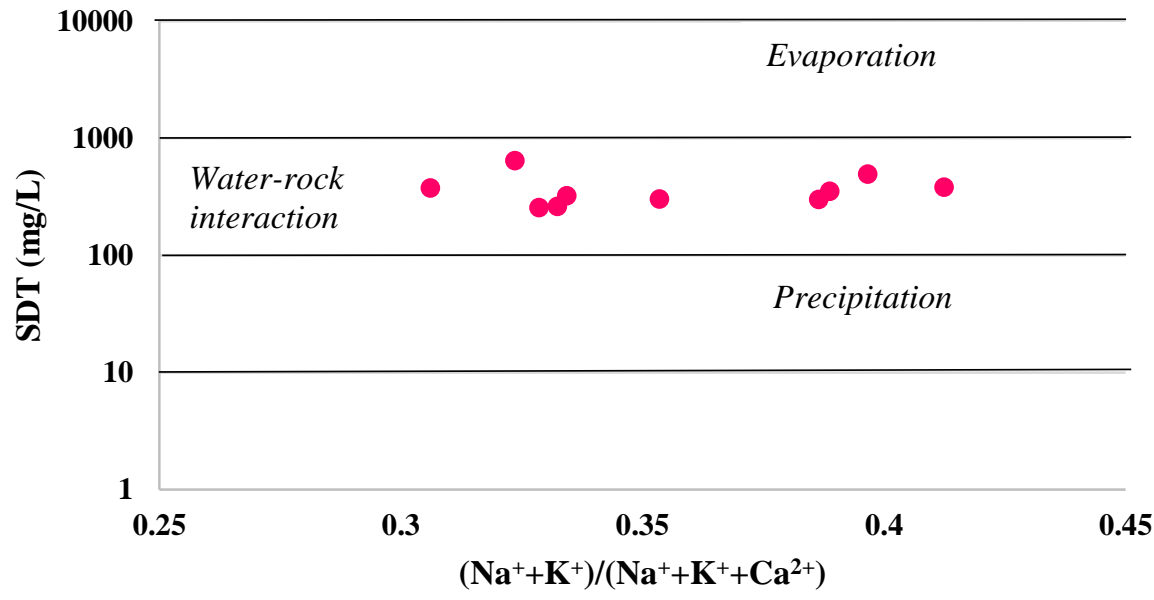

Figure 8. Gibbs diagram of the studied sites related to major cations.

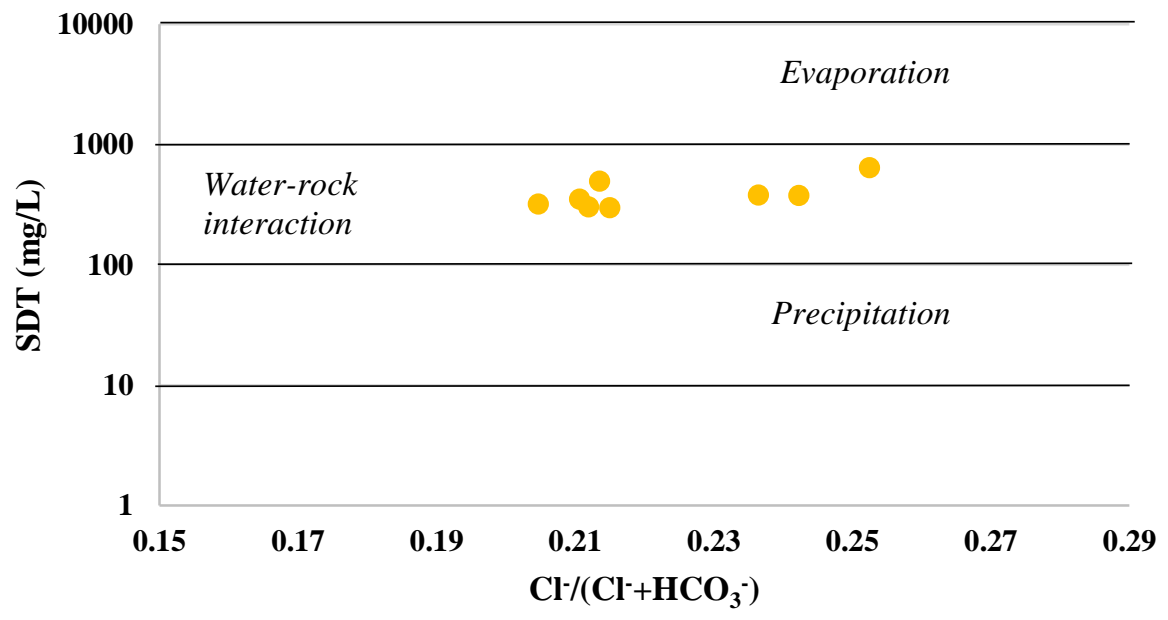

Figure 9. Gibbs diagram of the studied sites related to major anions. 


\subsubsection{Binary Ratios and Geochemical Processes}

Hydrogeochemical molar ratios are a useful tool to determine the origin of groundwater, and they allow understanding the reactions that occur on its way from the recharge zones to the discharge points. They have a direct relationship with the materials through which water circulates and with the phenomena that change its composition [36]. In this work, different ionic relationships were evaluated to understand the groundwater chemistry in the urban area of Zamora, Michoacán.

The weathering that affects some silicates that provide sodium to the water can alter the value of the $\mathrm{Na}^{+} / \mathrm{Cl}^{-}$ratio ratio. If the halite solution is responsible for the presence of $\mathrm{Na}^{+}$, this molar ratio is approximately 1 [37]. On the other hand, if the value of this ratio is $>1$, it can be assumed that $\mathrm{Na}^{+}$is released from a weathering reaction with silicates [18], with an ion-exchange process [22,38]. In the current studied area, the $\mathrm{Na}^{+} / \mathrm{Cl}^{-}$molar ratio varied from 1.268 to 1.861 , with an average of 1.616 , which means that all samples show $\mathrm{Na}^{+}$release as a result of a silicate weathering reaction process, as demonstrated by hydrochemical facies.

When the values of the $\mathrm{Ca}^{2+} / \mathrm{Mg}^{2+}$ ratio are close to 1.0, they indicate groundwater controlled by the dolomite solution, while values between 1 and 2 show the dissolution of the calcite. In natural waters where this proportion is greater than 2 , the dissolution of silicate minerals that contribute to the enrichment of $\mathrm{Ca}^{2+}$ and $\mathrm{Mg}^{2+}$ in groundwater can be assumed [22,35]. In the studied area, relationships between 2.18 and 5.43 were observed, with an average of 3.13 , indicating a process of dissolution of the silicate minerals, providing $\mathrm{Ca}^{2+}$ and $\mathrm{Mg}^{2+}$ from the rock to the groundwater.

When the values of the $\mathrm{Na}^{+} / \mathrm{K}^{+}$ratio are close to 1.0 , they indicate groundwater controlled by the dolomite solution, while values between 1 and 2 show the dissolution of the calcite. In natural waters where this proportion is greater than 2 , the dissolution of silicate minerals that contribute to the enrichment of $\mathrm{Ca}^{2+}$ and $\mathrm{Mg}^{2+}$ in groundwater can be assumed [22,35]. In the studied area, relationships between 2.18 and 5.43 were observed, with an average of 3.13 , indicating a process of dissolution of the silicate minerals, providing $\mathrm{Ca}^{2+}$ and $\mathrm{Mg}^{2+}$ from the rock to the groundwater.

Low values of the $\mathrm{Ca}^{2+} / \mathrm{SO}_{4}{ }^{2-}$ ratio indicate the elimination of calcium, either by precipitation as calcium carbonate, by ion-exchange processes, or both. These two processes are more abundant in shallow groundwater than in deep groundwater. Water with high $\mathrm{Ca}^{2+} / \mathrm{SO}_{4}{ }^{2-}$ ratios indicates the addition of calcium from the weathering of minerals rich in this element, other than gypsum [39]. In the studied area, values of this relationship between 2.25 and 3.56 were obtained, with an average of 3.03, showing weathering of $\mathrm{Ca}^{2+}$ processes from the aquifer rock.

The effect of the water-rock interaction predominates if the $\mathrm{Mg}^{2+} / \mathrm{Cl}^{-}$ratio is higher than 1.0, which indicates a more significant contribution of magnesium to the water as a result of the dissolution of magnesium silicates [40]. In the studied area, this proportion was observed between 0.91 and 1.64, with an average of 1.26. The interaction between water and rock prevail in most sites with a contribution of $\mathrm{Mg}^{2+}$ as a result of the dissolution of magnesium silicates. The ratio was less than 1.0 only at P8 site, showing a greater depth of the water.

Values greater than 1.0 of $\mathrm{HCO}_{3}{ }^{-} / \mathrm{Cl}^{-}$ratio are frequently observed in cold groundwater, with a short flow path and rapid circulation. Values under 1.0 indicate the presence of thermal water, with greater subsurface flow path and deep circulation [41]. In this study area, a range from 2.90 to 4.26 was obtained, indicating the presence of cold water of short and rapid path through the aquifer.

Figure 10 shows that $100 \%$ of the analyzed samples are under the $1: 1$ slope. This fact indicates that there is a deficiency of $\mathrm{Ca}^{2+}$ and $\mathrm{Mg}^{2+}$ compared to $\mathrm{HCO}_{3}{ }^{-}$. Thus, it is confirmed that $\mathrm{HCO}_{3}{ }^{-}$also comes from processes other than the dissolution of calcite or dolomite. In this case, and as established by the ionic relationships, it is supplied by the weathering of the silicates. 


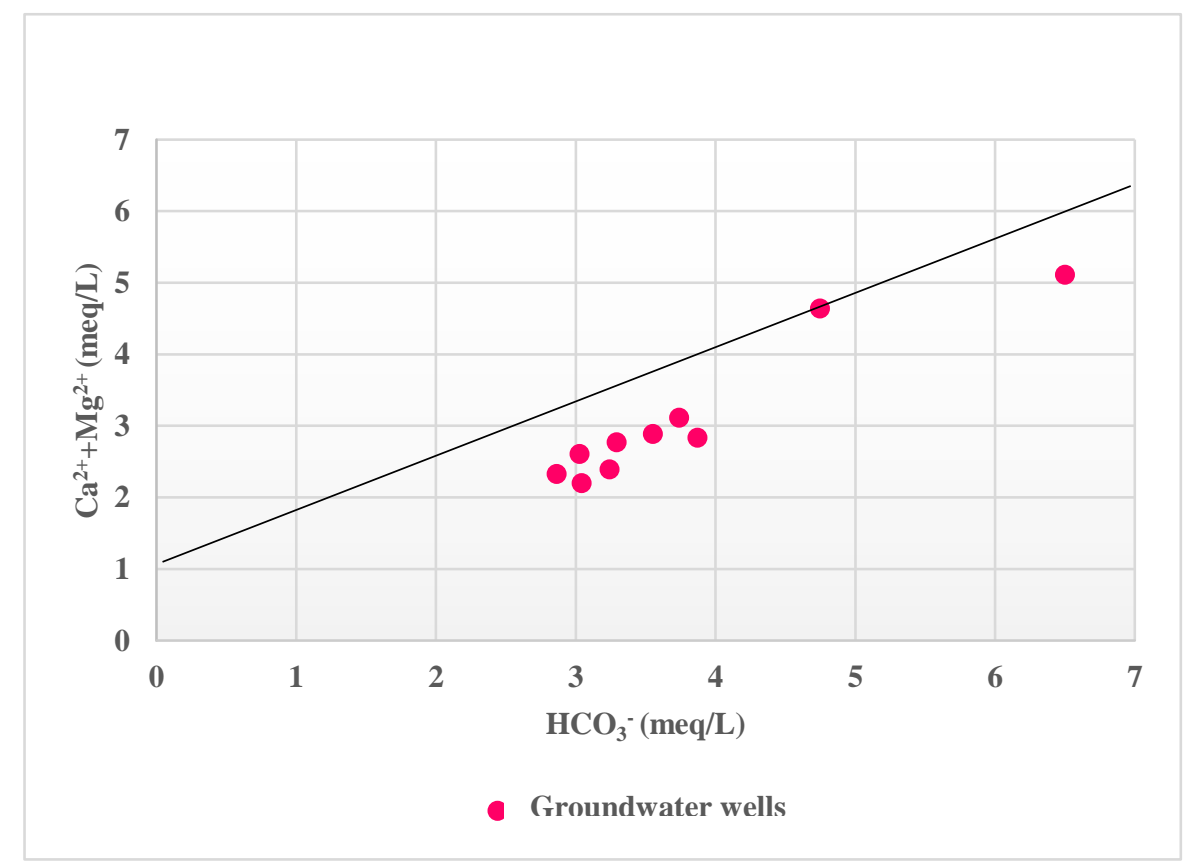

Figure 10. Binary hydrogeochemical diagram of the dissolution of calcite or dolomite in the study area.

Figure 11 presents the relationship between $\mathrm{SO}_{4}{ }^{2-}$ and $\mathrm{Cl}^{-}$. All samples in this area obtained $\mathrm{SO}_{4}{ }^{2-}$ as a result of the rainwater supply, and there is no interaction due to rock composition. There is no anthropogenic contamination since the concentrations are relatively low.

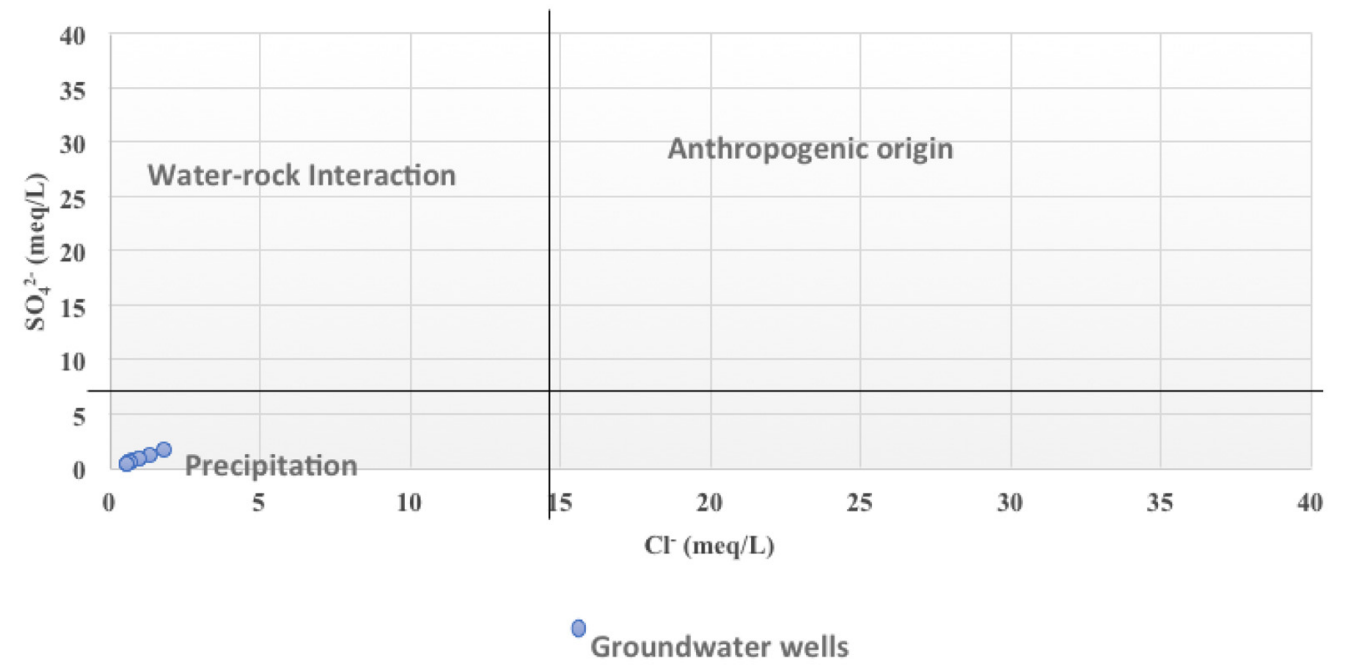

Figure 11. Binary diagram showing the origin of sulfates in groundwater in the studied area.

\subsubsection{Ion Exchange}

The chemical reactions in which ion exchange occurs between groundwater and the aquifer environment during residence and movement periods can be understood through the study of alkaline chlorine indices [34]. Schöeller [42] established an index to identify the ion-exchange processes between groundwater and its surroundings during residence as it passes through the aquifer. Chloro Alkaline Indices (CAI) can be positive or negative depending on the exchange of sodium and potassium in the rock with magnesium and calcium in the water and vice versa [43]. The positive CAI indicates the 
exchange of $\mathrm{Na}^{+}$and $\mathrm{K}^{+}$of the water with $\mathrm{Mg}^{2+}$ and $\mathrm{Ca}^{2+}$ of the rocks, and the negative indicates that there is an exchange of $\mathrm{Mg}^{2+}$ and $\mathrm{Ca}^{2+}$ of the water with $\mathrm{Na}^{+}$and $\mathrm{K}^{+}$of the rocks $[18,36]$. In the study area, a negative alkaline chlorine index was obtained, indicating the ionic exchange of $\mathrm{Mg}^{2+}$ and $\mathrm{Ca}^{2+}$ from the water with $\mathrm{Na}^{+}$and $\mathrm{K}^{+}$ions from the rock this because it is not a saline intrusion zone (Table 10). Equations (5) and (6) express the CAI. The concentrations are in meq/L:

$$
\begin{gathered}
\mathrm{CAI} 1=\frac{\mathrm{Cl}^{-}-\left(\mathrm{Na}^{+}+\mathrm{K}^{+}\right)}{\mathrm{Cl}^{-}} \\
\mathrm{CAI} 2=\frac{\mathrm{Cl}^{-}-\left(\mathrm{Na}^{+}+\mathrm{K}^{+}\right)}{\mathrm{SO}_{4}^{2-}+\mathrm{HCO}_{3}^{-}+\mathrm{CO}_{3}^{2-}+\mathrm{NO}_{3}^{-}}
\end{gathered}
$$

Table 10. Molar ratio values of the groundwater of Zamora, Michoacán.

\begin{tabular}{ccccccccc}
\hline SITE & $\mathbf{N a}^{+} / \mathbf{C l}^{-}$ & $\mathbf{C a}^{2+} / \mathbf{M g}^{2+}$ & $\mathbf{N a}^{+} / \mathbf{K}^{+}$ & $\mathbf{C a}^{2+} / \mathbf{S O}_{4}{ }^{2-}$ & $\mathbf{M g}^{2+} / \mathbf{C l}^{-}$ & $\mathbf{H C O}_{3}{ }^{-} / \mathbf{C l}^{-}$ & $\mathbf{C A I ~ 1}$ & $\mathbf{C A I} \mathbf{2}$ \\
\hline P1 & 1.689 & 4.409 & 4.878 & 2.824 & 1.084 & 3.265 & -1.034 & -0.195 \\
P2 & 1.524 & 2.393 & 4.333 & 2.797 & 1.240 & 3.368 & -0.876 & -0.165 \\
P3 & 1.268 & 5.433 & 4.077 & 2.723 & 1.010 & 2.903 & -0.579 & -0.118 \\
P4 & 1.861 & 2.349 & 3.018 & 2.249 & 1.477 & 3.637 & -1.472 & -0.263 \\
P5 & 1.379 & 2.630 & 3.450 & 2.517 & 1.492 & 3.245 & -0.779 & -0.148 \\
P6 & 1.616 & 2.563 & 2.516 & 3.371 & 1.262 & 3.363 & -1.260 & -0.242 \\
P7 & 1.762 & 2.643 & 3.789 & 3.349 & 1.119 & 3.461 & -1.227 & -0.231 \\
P8 & 1.602 & 3.568 & 3.563 & 3.386 & 0.912 & 3.647 & -1.054 & -0.190 \\
P9 & 1.828 & 3.101 & 2.727 & 3.540 & 1.330 & 4.260 & -1.490 & -0.232 \\
P10 & 1.631 & 2.179 & 3.003 & 3.555 & 1.641 & 3.830 & -1.182 & -0.205 \\
\hline
\end{tabular}

Figures 12 and 13 show CAI 1 and CAI 2 types obtained, respectively.

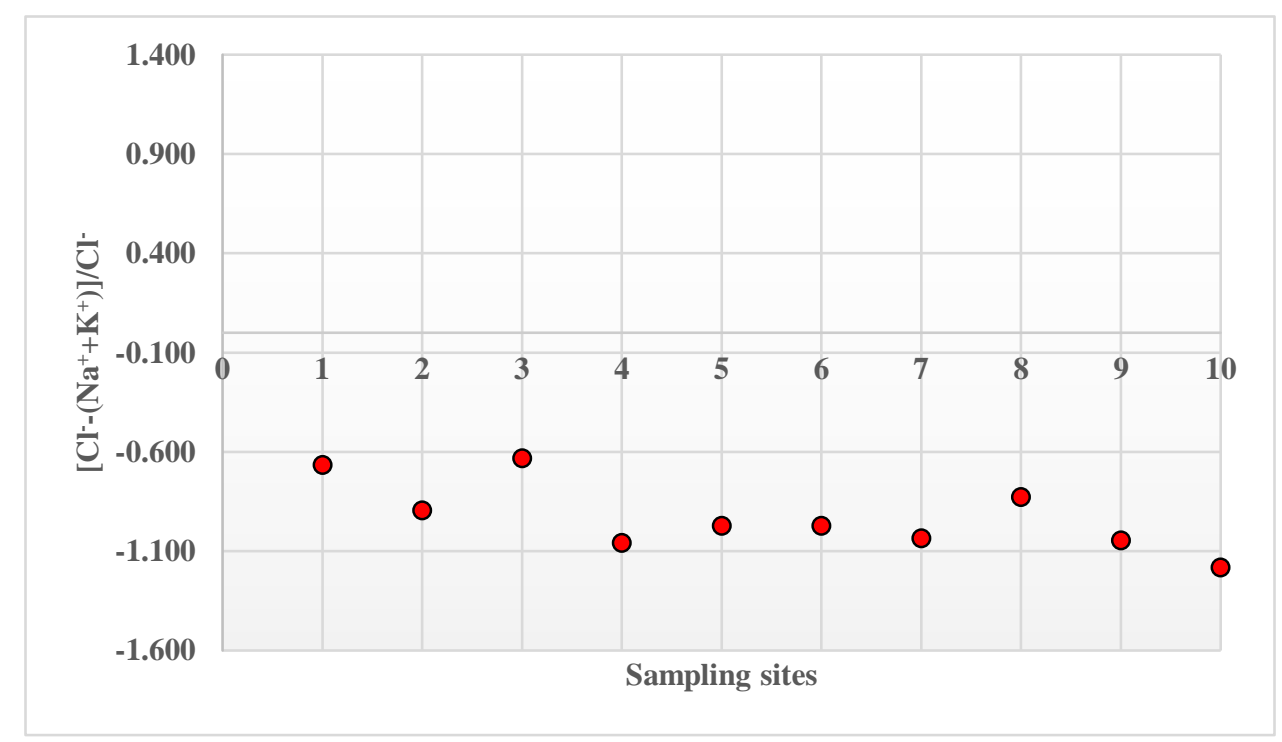

Figure 12. Chloro Alkaline Index type 1 (CAI 1) to determine the type of ion exchange occurred in the studied area. 


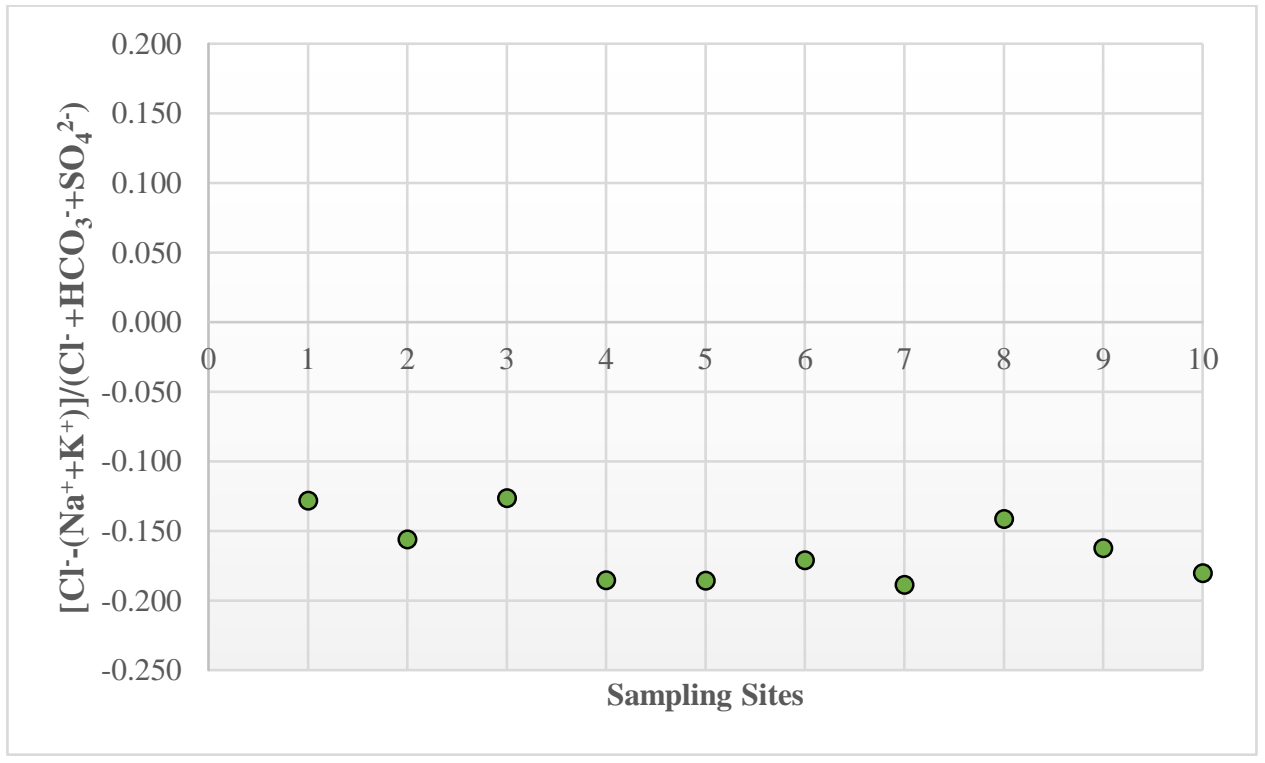

Figure 13. Chloro Alkaline Index type 2 (CAI 2) to determine the type of ion exchange occurred in the studied area.

\subsection{Water Quality Index}

The weighted arithmetic average method was used in these calculations. This method for calculating the WQI considers the maximum permissible limits for any regulations, whether national [13] or international [44], and can be adapted to the needs of the type of study being carried out. However, it has certain limitations, such as that it is not possible to evaluate all the risks present in the water, and the weighting required for each parameter according to its importance could become subjective.

The results obtained in the studied area ranged between 30.4 and 72.4 (Table 11), observing water of excellent and good quality.

Table 11. Water Quality Index in the urban zone of Zamora, Mexico.

\begin{tabular}{ccc}
\hline Site & WQI & Water Quality \\
\hline P1 & 38.29 & Excellent \\
P2 & 45.97 & Excellent \\
P3 & 59.02 & Good \\
P4 & 38.85 & Excellent \\
P5 & 41.01 & Excellent \\
P6 & 33.56 & Excellent \\
P7 & 71.35 & Good \\
P8 & 72.44 & Good \\
P9 & 36.16 & Excellent \\
P10 & 30.48 & Excellent \\
\hline
\end{tabular}

\section{Conclusions}

This study allows knowledge of the hydrogeochemistry and drinking water quality in the urban area of Zamora, Mexico, and may be useful for subsequent research since there is no previous information on the chemistry of water in this zone. The groundwater of the studied area presented a slight tendency to alkalinity. The order of abundance of major ions in this study is $\mathrm{HCO}_{3}{ }^{-}>\mathrm{Ca}^{2+}>\mathrm{Na}^{+}$ $>\mathrm{Mg}^{2+}>\mathrm{Cl}^{-} \approx \mathrm{SO}_{4}{ }^{2-}>\mathrm{K}^{+}>\mathrm{CO}_{3}{ }^{2-}>\mathrm{PO}_{4}{ }^{3-} \approx \mathrm{N}_{-} \mathrm{NO}_{3}{ }^{-}>\mathrm{N}-\mathrm{NH}_{3}$. The presence of $\mathrm{Mn}, \mathrm{Ba}, \mathrm{V}, \mathrm{Fe}, \mathrm{Sb}$, $\mathrm{Co}$, and As was found at all sites. Copper and aluminum concentrations were also observed in five sites. No trace element exceeded the recommendations of both Mexican and international regulations for drinking water. The chemical mobility speciation of trace elements showed $\mathrm{HAsO}_{4}{ }^{2-}, \mathrm{Fe}(\mathrm{OH})_{2}{ }^{+}, \mathrm{Mn}^{2+}$, 
$\mathrm{Ba}^{2+}, \mathrm{VOH}^{2+}$, and $\mathrm{V}(\mathrm{OH})_{2}{ }^{+}$as the predominant species in the studied area. The hydrogeochemical facies are $\mathrm{Ca}^{2+}-\mathrm{HCO}_{3}{ }^{-}$in all sites, which means that probably all wells are supplied by the same aquifer, and the groundwater is of recent infiltration. Hydrochemical diagrams indicate young or immature, cold, non-saline, and uncontaminated water with short residence time. The water-rock interaction controls the chemistry of groundwater in the studied area, where the main process that affects the chemistry of water is the dissolution of carbonates and silicates. This process of water-rock interaction includes the chemical weathering of rocks, the dissolution-precipitation of secondary carbonates, and the ionic exchange between water and clay minerals in the area, as confirmed by the binary ratios. The water in the study area is suitable for human use and consumption according to Mexican and international regulations with excellent quality in 7 wells and good in the other 3 .

Author Contributions: Conceptualization, R.A.-C.-V. and R.C.-M.; methodology, C.A.R.-T.; software, C.A.R.-T.; validation, O.M.-B., E.H.-Á. and C.A.R.-T; formal analysis, R.A.-C.-V, O.B.-D and C.A.R.-T.; writing-original draft preparation, C.A.R.-T., R.A.-C.-V, and J.A.Á.-O.; writing-review and editing R.C.-M., J.A.Á.-O. and O.B.-D.; project administration, R.A.-C.-V. All authors have read and agreed to the published version of the manuscript.

Funding: This research was funded by CIC-UMSNH, grant number CIC-2019 and The APC was funded by PRODEP.

Acknowledgments: The authors wish to thank Juan Rangel Camarena for his valuable participation in the physicochemical analyses.

Conflicts of Interest: The authors declare no conflict of interest.

\section{References}

1. Ruiz, Á.; Cuenca, Á.; Agila, R.; Criollo, D.; Leiva, J.; Salazar, J. Hydrochemical characterization of groundwater in the Loja Basin (Ecuador). Appl. Geochem. 2019, 104, 1-9. [CrossRef]

2. Busico, G.; Cuoco, E.; Kazakis, N.; Colombani, N.; Mastrocicco, M.; Tedesco, D.; Voudouris, K. Multivariate statistical analysis to characterize/discriminate between anthropogenic and geogenic trace elements occurrence in the Campania Plain, Southern Italy. Environ. Pollut. 2018, 234, 260-269. [CrossRef] [PubMed]

3. Saravanan, K.; Srinivasamoorthy, K.; Prakash, R.; Gopinath, S.; Suma, C. An Evaluation of hydrogeochemistry of groundwater in upper vellar sub-basin using mineral stability and solute transport modelling. Aquat. Procedia 2015, 4, 1119-1125. [CrossRef]

4. Salcedo, E.; Garrido, S.; Vicenta, M.; Martínez, M.; Ocampo, A. Hydrogeochemistry and water-rock interactions in the urban area of Puebla Valley aquifer (Mexico). J. Geochem. Explor. 2017, 181, 219-235. [CrossRef]

5. Gnanachandrasamy, G.; Ramkumar, T.; Venkatramanan, S.; Vasudevan, S.; Chung, S.; Bagyaraj, M. Accessing groundwater quality in lower part of Nagapattinam district, Southern India: Using hydrogeochemistry and GIS interpolation techniques. Appl. Water Sci. 2015, 5, 39-55. [CrossRef]

6. CONAGUA. Actualización de la Disponibilidad Media Anual de Agua en el Acuífero Zamora, Estado de Michoacán. Zamora, Michoacán; DOF: Mexico City, México, 2015; pp. 1-26.

7. INEGI. Compendio de Información Geográfica Municipal 2010 Zamora, Michoacán de Ocampo; INEGI: Mexico city, Mexico, 2010.

8. INAFED. Instituto Para el Federalismo y el Desarrollo Municipal. Available online: http://www.inafed.gob. mx/work/enciclopedia/EMM16michoacan/municipios/16108a.html (accessed on 15 December 2019).

9. Alfaro, R.; Martínez, V.; Segovia, N.; Peña, P.; López, M.B.E.; Armienta, M.A.; Rangel, J.; Seidel, J.L. Radon behavior in springs and wells around Cuitzeo Lake, Lerma River basin. Geofís. Int. 2002, 41, 439-445.

10. APHA-WWA-WPC. Standard Methods for the Examination Water and Wastewater, 21st ed.; APHA-AWWA-WPCF, Ed.; APHA-AWWA-WPC: Washington, DC, USA, 2005.

11. Brown, R.M.; McClelland, N.I.; Deininger, R.A.; Tozer, R.G. A water quality index: Do we dare? Water Sew. Works 1970, 117, 339-343.

12. Sadat-Noori, S.; Ebrahimi, K.; Liaghat, A. Groundwater quality assessment using the Water Quality Index and GIS in Saveh-Nobaran aquifer, Iran. Environ. Earth Sci. 2014, 71, 3827-3843. [CrossRef] 
13. DOF. Modificación de la Norma Oficial Mexicana NOM-127-SSA1-1994. Salud Ambiental. Agua para uso y consumo humano. Límites permisibles de calidad y tratamientos a que debe someterse el agua para su potabilización. Secretaría de Salud. Diario Oficial de la Federación. 1994. Available online: http://www.salud.gob.mx/unidades/cdi/nom/m127ssa14.html (accessed on 9 February 2020).

14. Gubran, M.; Ghrefat, H.; Zaidi, F.; Shehata, M. Integration of hydrochemical, GIS, and remote-sensing data for assessment of shallow groundwater aquifers in Wadi Nisah, Central Saudi Arabia. Environ. Earth Sci. 2019, 78, 161. [CrossRef]

15. Nas, B.; Berktay, A. Groundwater quality mapping in urban groundwater using GIS. Environ. Monit. Assess. 2010, 160, 215-227. [CrossRef] [PubMed]

16. Alacali, M. Hydrogeochemical investigation of geothermal springs in Erzurum, East Anatolia (Turkey). Environ. Earth Sci. 2018, 77, 802. [CrossRef]

17. Das, S.; Nag, S. Application of multivariate statistical analysis concepts for assessment of hydrogeochemistry of groundwater-A study in Suri I and II blocks of Birbhum District, West Bengal, India. Appl. Water Sci. 2017, 7, 873-888. [CrossRef]

18. Berhe, B.A.; Dokuz, U.E.; Çelik, M. Assessment of hydrogeochemistry and environmental isotopes of surface and groundwaters in the Kütahya Plain, Turkey. J. Afr. Earth Sci. 2017, 134, 230-240. [CrossRef]

19. Voutsis, N.; Kelepertzis, E.; Tziritis, E.; Kelepertsis, A. Assessing the hydrogeochemistry of groundwaters in ophiolite areas of Euboea Island, Greece, using multivariate statistical methods. J. Geochem. Explor. 2015, 159, 79-92. [CrossRef]

20. Wu, C.; Wu, X.; Qian, C.; Zhu, G. Hydrogeochemistry and groundwater quality assessment of high fluoride levels in the Yanchi endorheic region, northwest China. Appl. Geochem. 2018, 98, 404-417. [CrossRef]

21. Morán-Ramírez, J.; Ledesma-Ruíz, R.; Mahlknecht, J.; Ramos-Leal, J. Rock-water interactions and pollution processes in the volcanic aquifer system of Guadalajara, Mexico, using inverse geochemical modeling. Appl. Geochem. 2016, 68, 79-94. [CrossRef]

22. Redwan, M.; Moneim, A.A.A. Factors controlling groundwater hydrogeochemistry in the area west of Tahta, Sohag, Upper Egypt. J. Afr. Earth Sci. 2016, 118, 328-338. [CrossRef]

23. Khan, R.; Jhariya, D. Hydrogeochemistry and Groundwater Quality Assessment for Drinking and Irrigation Purpose of Raipur City, Chhattisgarh. J. Geol. Soc. India 2018, 91, 475-482. [CrossRef]

24. Gonzalez Flores, E.; Tornero Campante, M.A.; Angeles Cruz, Y.; Bonilla y Fernandez, N. Concentración total y especiación de metales pesados en biosólidos de origen urbano. Rev. Int. Cont. Amb. 2009, 25, 15-22.

25. Okan, Ö.Ö.; Kalender, L.; Çetindă̆, B. Trace-element hydrogeochemistry of thermal waters of Karakoçan (Elazığ) and Mazgirt (Tunceli), Eastern Anatolia, Turkey. J. Geochem. Explor. 2018, 194, 29-43. [CrossRef]

26. Giménez-Forcada, E.; Vega-Alegre, M. Arsenic, barium, strontium and uranium geochemistry and their utility as tracers to characterize groundwaters from the Espadán-Calderona Triassic Domain, Spain. Sci. Total Environ. 2015, 512, 599-612. [CrossRef] [PubMed]

27. Fiorentino, C.E.; Paoloni, J.D.; Sequeira, M.E.; Arosteguy, P. The presence of vanadium in groundwater of southeastern extreme the pampean region Argentina: Relationship with other chemical elements. J. Contam. Hydrol. 2007, 93, 122-129. [CrossRef] [PubMed]

28. Paradis, C.J.; Johnson, R.H.; Tigar, A.D.; Sauer, K.B.; Marina, O.C.; Reimus, P.W. Field experiments of surface water to groundwater recharge to characterize the mobility of uranium and vanadium at a former mill tailing site. J. Contam. Hydrol. 2019, 229, 103581. [CrossRef] [PubMed]

29. Pourret, O.; Dia, A.; Gruau, G.; Davranche, M.; Coz, M. Assessment of vanadium distribution in shallow groundwaters. Chemical Geol. 2012, 294-295, 89-102. [CrossRef]

30. Venkatramanan, S.; Chung, S.Y.; Ramkumar, T.; Gnanachandrasamy, G.; Vasudevan, S.; Lee, S. Application of GIS and hydrogeochemistry of groundwater pollution status of Nagapattinam district of Tamil Nadu, India. Environ. Earth Sci. 2015, 73, 4429-4442. [CrossRef]

31. Sharifi, R.; Moore, F.; Mohammadi, Z.; Keshavarzi, B. Estimation of deepwater temperature and hydrogeochemistry of springs in the Takab geothermal field, West Azerbaijan, Iran. Environ. Monit. Assess. 2016, 188, 75. [CrossRef] [PubMed]

32. Giggenbach, W.F. Geothermal solute equilibria. Derivation of Na-K-Mg-Ca geoindicators. Geochim. Cosmochim. Acta 1988, 52, 2749-2765. [CrossRef] 
33. Gaikwad, S.; Gaikwad, S.; Meshram, D.; Wagh, V.; Kandekar, A.; Kadam, A. Geochemical mobility of ions in groundwater from the tropical western coast of Maharashtra, India: Implication to groundwater quality. Environ. Dev. Sustain. 2019, 21, 1-34. [CrossRef]

34. Raju, N.J.; Shukla, U.K.; Ram, P. Hydrogeochemistry for the assessment of groundwater quality in Varanasi: A fast-urbanizing center in Uttar Pradesh, India. Environ. Monit. Assess. 2011, 173, 279-300. [CrossRef]

35. Sheikh, M.A.; Azad, C.; Mukherjee, S.; Rina, K. An assessment of groundwater salinization in Haryana state in India using hydrochemical tools in association with GIS. Environ. Earth Sci. 2017, 76, 465. [CrossRef]

36. Mahmoudi, N.; Nakhaei, M.; Porhemmat, J. Assessment of hydrogeochemistry and contamination of Varamin deep aquifer, Tehran Province, Iran. Environ. Earth Sci. 2017, 76, 370. [CrossRef]

37. Chang, J.; Wang, G. Major ions chemistry of groundwater in the arid region of Zhangye Basin, northwestern China. Environ. Earth Sci. 2010, 61, 539-547. [CrossRef]

38. Esteller, M.V.; Kondratenko, N.; Expósito, J.L.; Medina, M.; Del Campo, M.M. Hydrogeochemical characteristics of a volcanic-sedimentary aquifer with special emphasis on Fe and Mn content: A case study in Mexico. J. Geochem. Explor. 2017, 180, 113-126. [CrossRef]

39. Salem, Z.E.S.; Osman, O.M. Use of major ions to evaluate the hydrogeochemistry of groundwater influenced by reclamation and seawater intrusion, West Nile Delta, Egypt. Environ. Sci. Pollut. Res. 2017, 24, 3675-3704. [CrossRef]

40. Custodio, E.; Llamas, M. Hidrología Subterránea Volume 2, 1st ed.; Barcelona, O., Ed.; Omega: Barcelona, Spain, 1996.

41. Cuoco, E.; Verrengia, G.; De Francesco, S.; Tedesco, D. Hydrogeochemistry of Roccamonfina volcano (southern Italy). Environ. Earth Sci. 2010, 61, 525-538. [CrossRef]

42. Schoeller, H. Los Eaux Souterraines; Masson \& Cie. Editeurs: París, France, 1962.

43. Kumar, S.K.; Bharani, R.; Magesh, N.S.; Godson, P.S.; Chandrasekar, N. Hydrogeochemistry and groundwater quality appraisal of part of south Chennai coastal aquifers, Tamil Nadu, India using WQI and fuzzy logic method. Appl. Water Sci. 2014, 4, 341-350. [CrossRef]

44. USEPA. National Recommended Water Quality Criteria; United States Environmental Protection Agency', Office of Water, Office of Science and Technology. Available online: https://www.epa.gov/wqc (accessed on 9 February 2020).

(C) 2020 by the authors. Licensee MDPI, Basel, Switzerland. This article is an open access article distributed under the terms and conditions of the Creative Commons Attribution (CC BY) license (http://creativecommons.org/licenses/by/4.0/). 